\title{
الملصق السياسي بمصر وأثر التكنولوجيا الرقمية على تصميمه \\ The Political Poster In Egypt And The Digital Technology Impact On Its Design
}

المدرس بقسم الجرافيك - كلية الفنون الجميلة - جامعة المنصورة

هاني محمد فريد حسن

مقدمة

لا شك في أن الملصق قد لعب دورًا هامًا في تاريخ الحركات السياسية العالمية، وإرتبط بها إرتباطًا وثيقًا، بدءًا من الإتحاد العاد العاديا

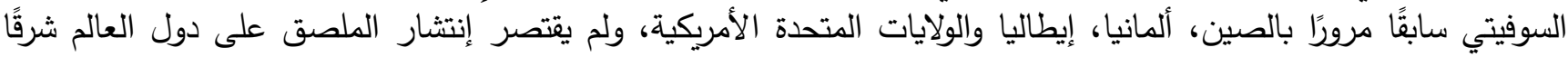

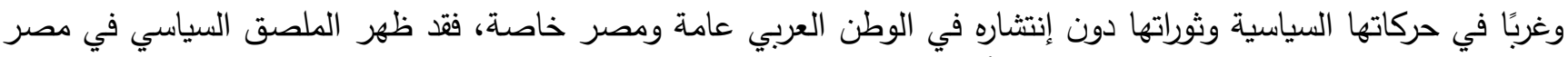

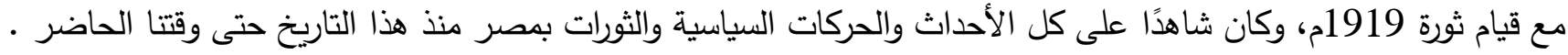

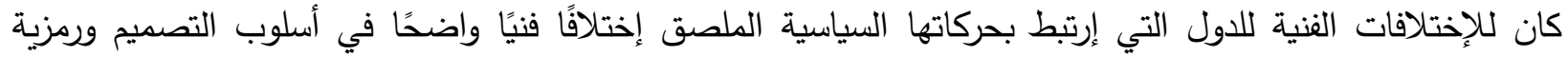

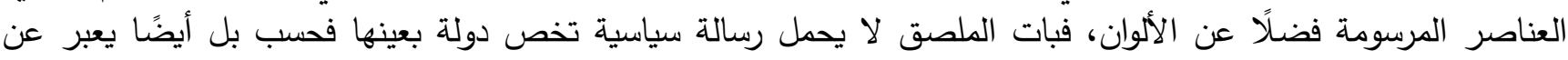

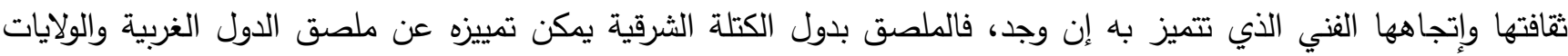

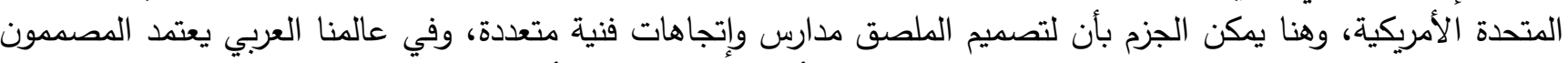

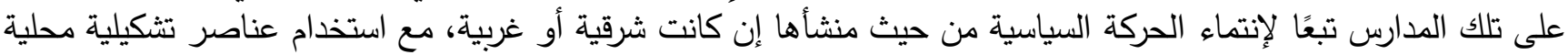

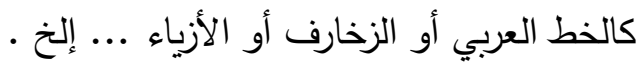

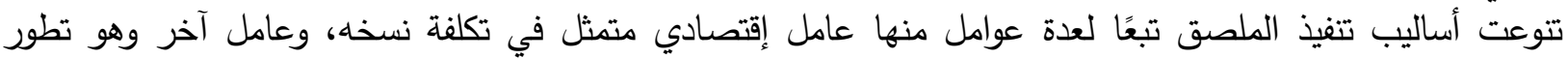

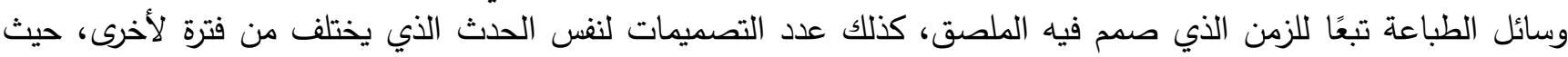

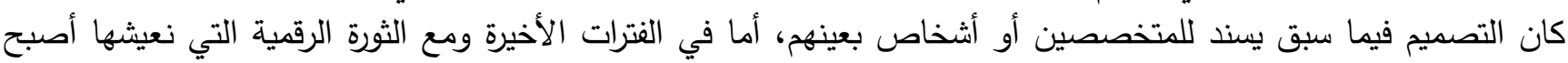

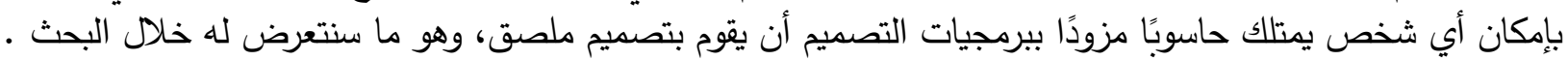

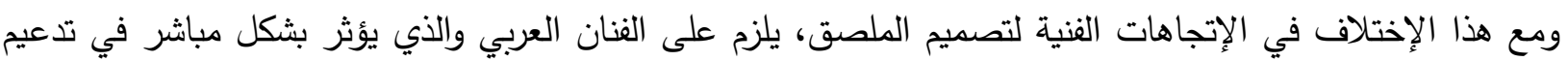

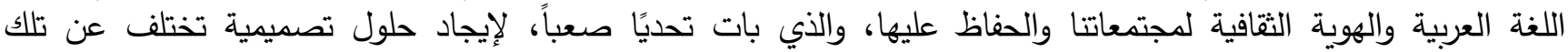

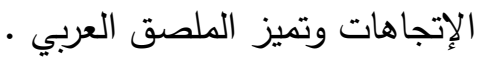

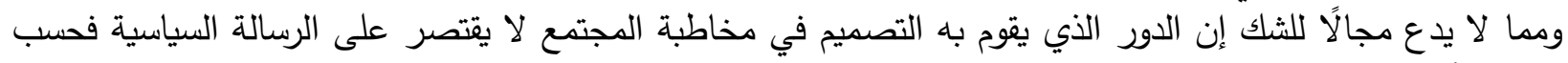
بل من المؤكد أنه يقوم بدور تثقيفي وتوعوي من خلال اللغة البصرية ومفرداتها التشكيلية والتي تساهم بشكل كبير في تشكيل

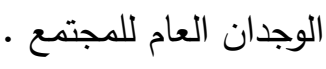

من هنا تأتي أهمية اللغة ومفرداتها كنص مكتوب أحد العناصر الرئيسية التي يتشكل منها تصميم الملصق بجانب العناصر البصرية الأخرى علاوة على ما تحمله من أفكار، وهو ما يؤثر بثكل غير مباشير على على سلوكيات وثقافة المجتمع بل

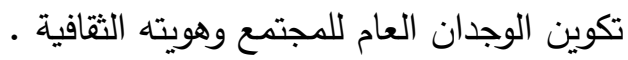

مشكلة البحث المثام

- تأخر تصميم الملصق العربي في البحث عن هوية خاصة به مقارنة بالثقافات الأخرى .

- الدور السلبي بل والمؤثر في إتساع الفجوة بين محتوى الملصق من حيث التصميم والأفكار والمبادئ السياسية المراد

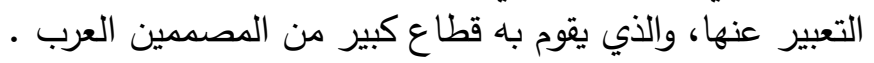

- العوامل التي تساهم بشكل كبير في إتساع الفجوة بين تصميم الملصق والهدف السياسي المرجو منه . - المؤثرات الإجتماعية والتطور التكنولوجي والذي ساهم في في ترسيخ التيخ فئ فكر العولمة . فروض البحث ومسلماته - الملصق يعتبر عنصرًا هامًا في الحركات السياسية، وله أهمية في التعبير عن مبادئها ومطالبها .

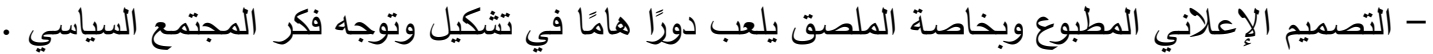

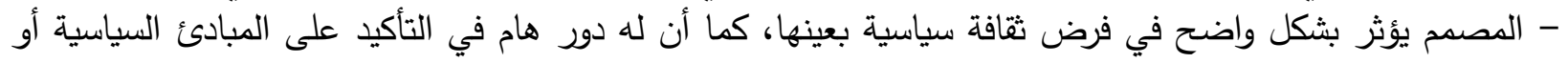
المطالب الثورية .

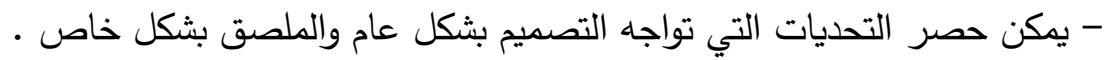

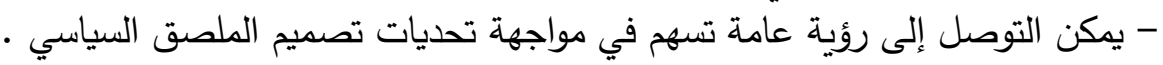


- التأكيد على أهمية تصميم الملصق كوسيلة هامة يمكن من خلالها توجيه أفكار المجتمع لفكر سياسي بعينه .

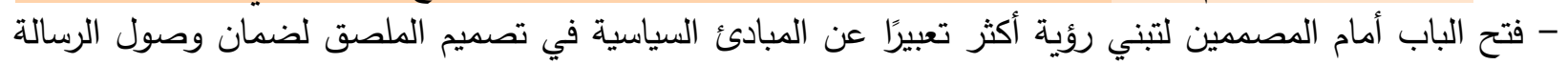

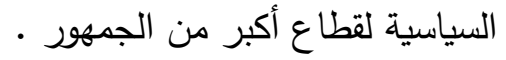

أهمية البحث

- تسليط الضوء على معوقات تصميم الملصق ومدى إتساقه مع الرسالة السياسية المراد إيصالها .

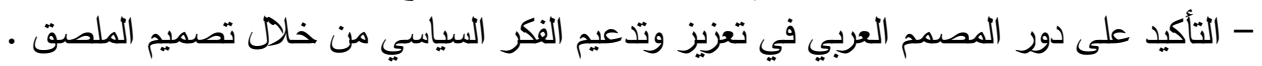
حدود البحث تتركز فترة البحث الزمانية خلال القرن العشرين وبدايات القرن الحادي والعشرين، أما الحدود المكانية فتقع في مصر . منهج البحث يتبع البحث المنهج التحليلي والتاريخي حيث يقوم بتحليل ودراسة تصميمات الملصقات وكذلك أثرها على المجتمع وهويته ومدى تأثيرها فيه .

\section{ثورة 1919م}

كان أول ظهور للملصق السياسي بمصر بشكل واضح مع بدايات ثورة 1919م، والتي كانت التي سلسلة من الإحتجاجات

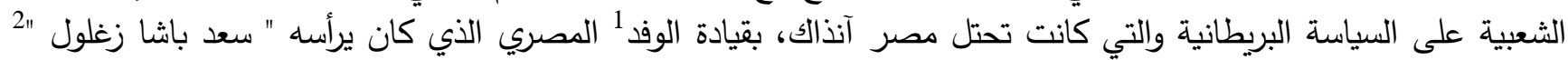

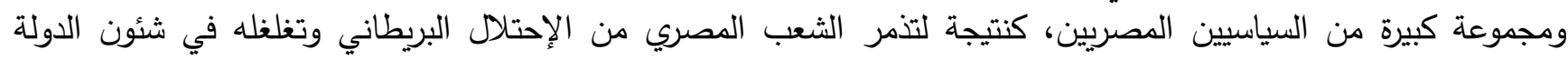

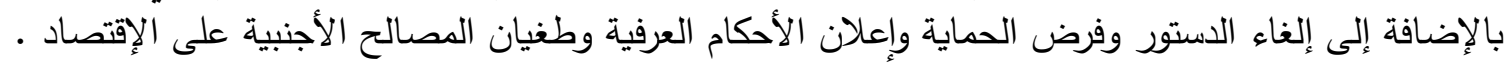

كانت الشرارة التي أشعلت الثثرة هي إعتقال بريطانيا لأربعة من الوفد المصري المنوط به السفر إلى إلى مؤتمر باريس للسلام

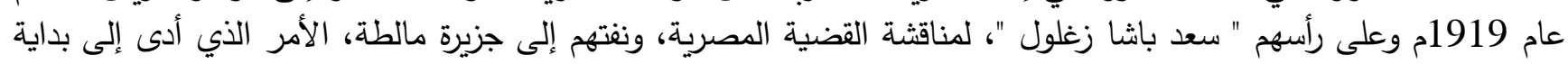

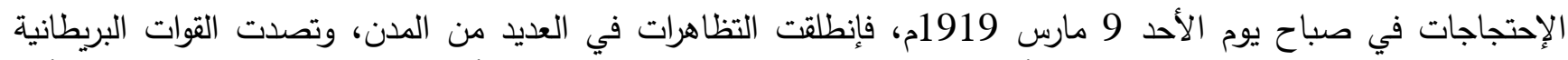

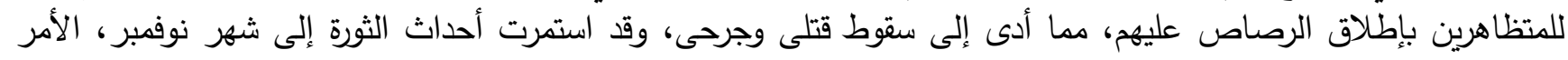

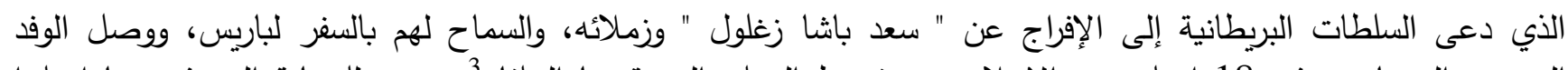

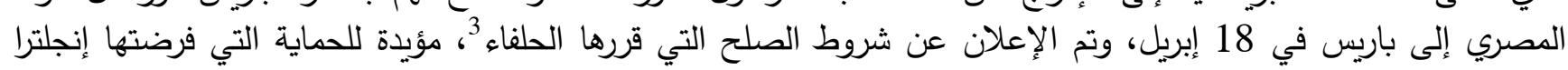

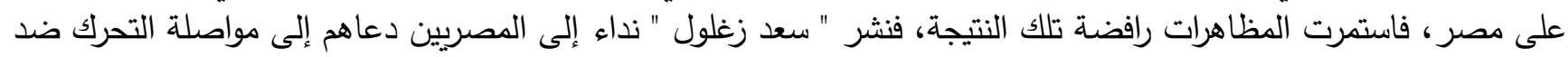

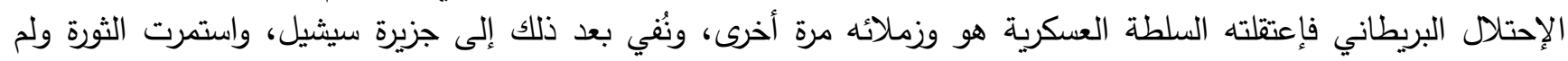

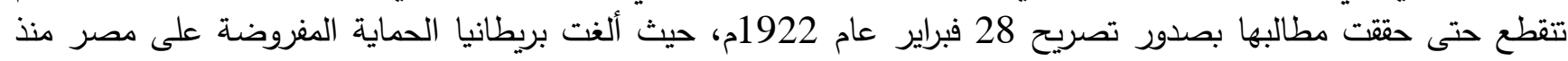

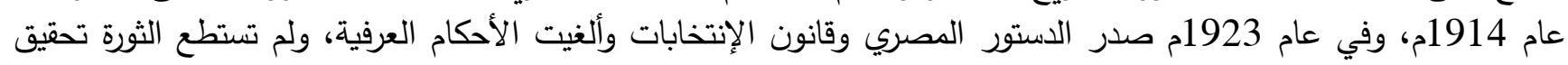
الاستقلال التام، فقد ظلت القوات البريطانية متواجدة في مصر ل

كان من أهم سمات هذه الثورة هي تلاحم كل مكونات الثعب مسلمين ومسيحيين، لذلك نجد بزوغ شعار الهلال يحتضن

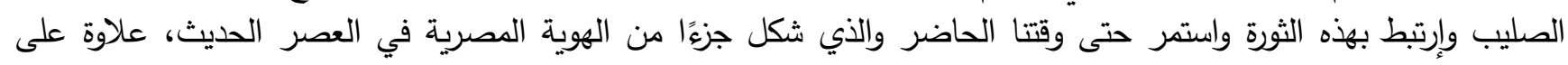
استخدام الهلال والثلاث نجوم وهو علم مصر في تلك الفترة، ويتصدر هذا الثعار معظم الملصقات ويمثل العنصر الرئيسي في في التصميم - شكل رقم 1 - - ن

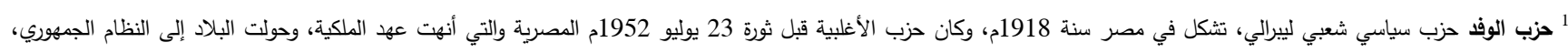

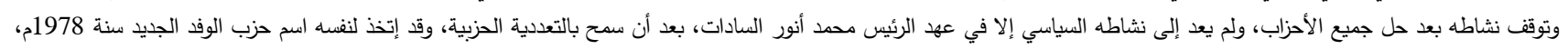

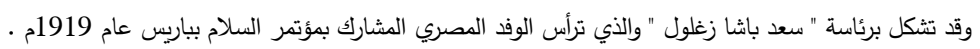

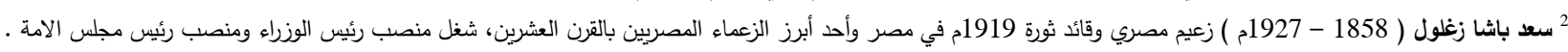

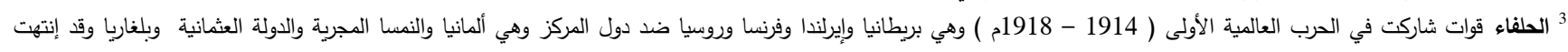




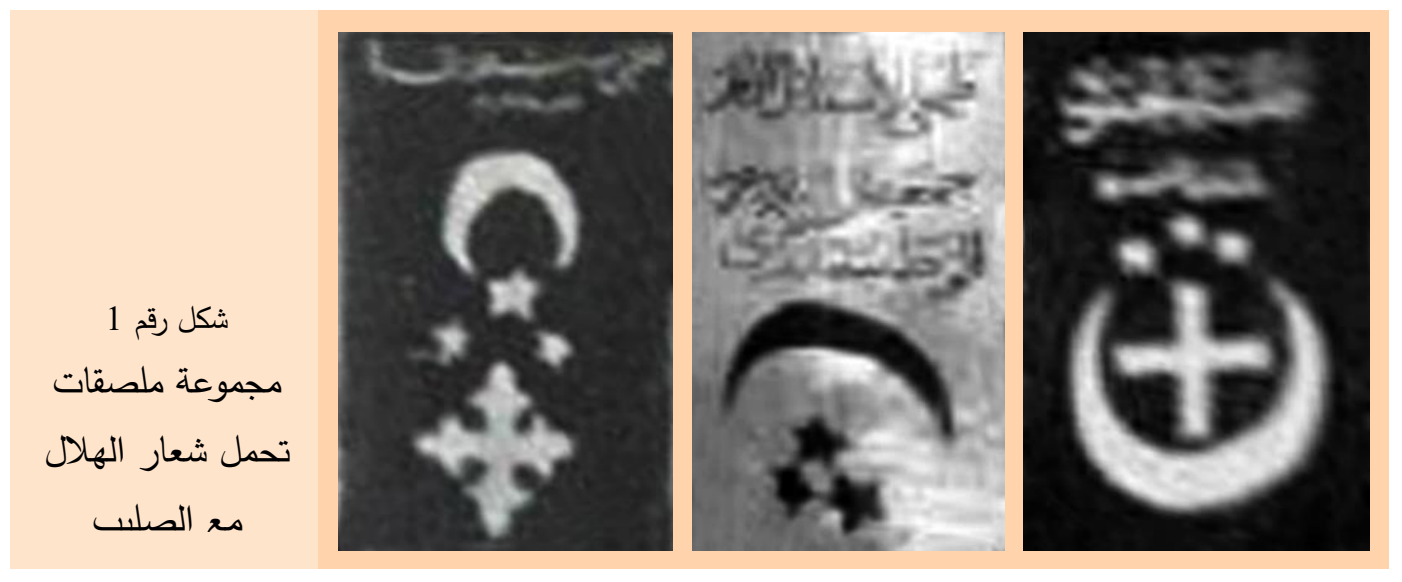

وبما أن " سعد باشا زغلول " كان يمثل رمزًا للثورة، فقد كان عنصرًا أساسيًا في تصميم بعض الملصقات - شكل رقم 2 -

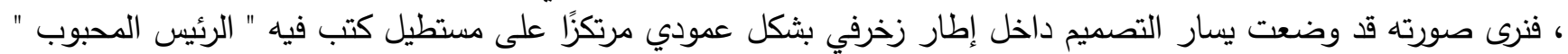

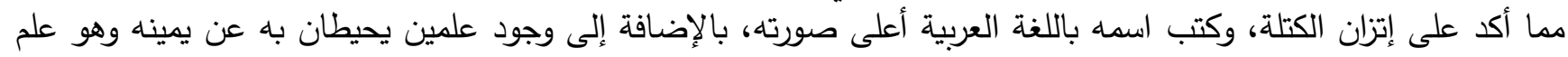

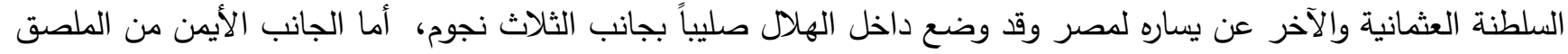

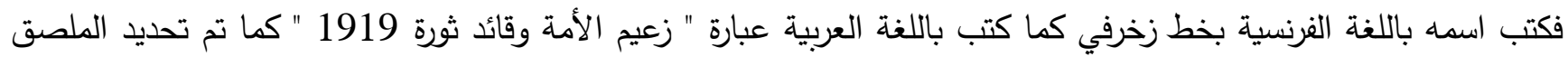

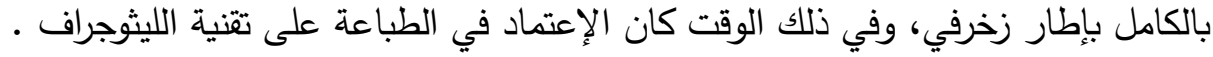

وفي ملصق آخر - شكل رقم 3 - نجد صورته بمنتصف الملصق وقد تم تأطيرها بإطار زخرفي بشكل عمودي مرتكزًا

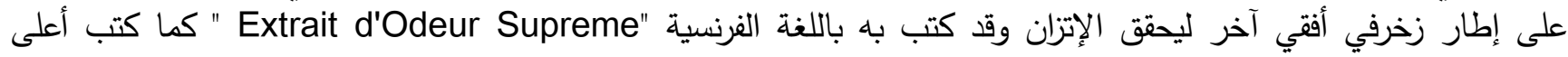

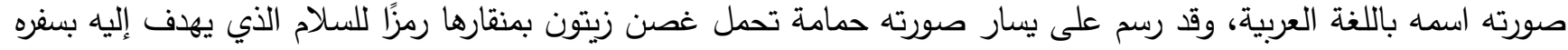

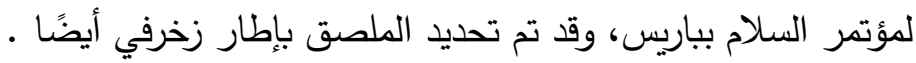

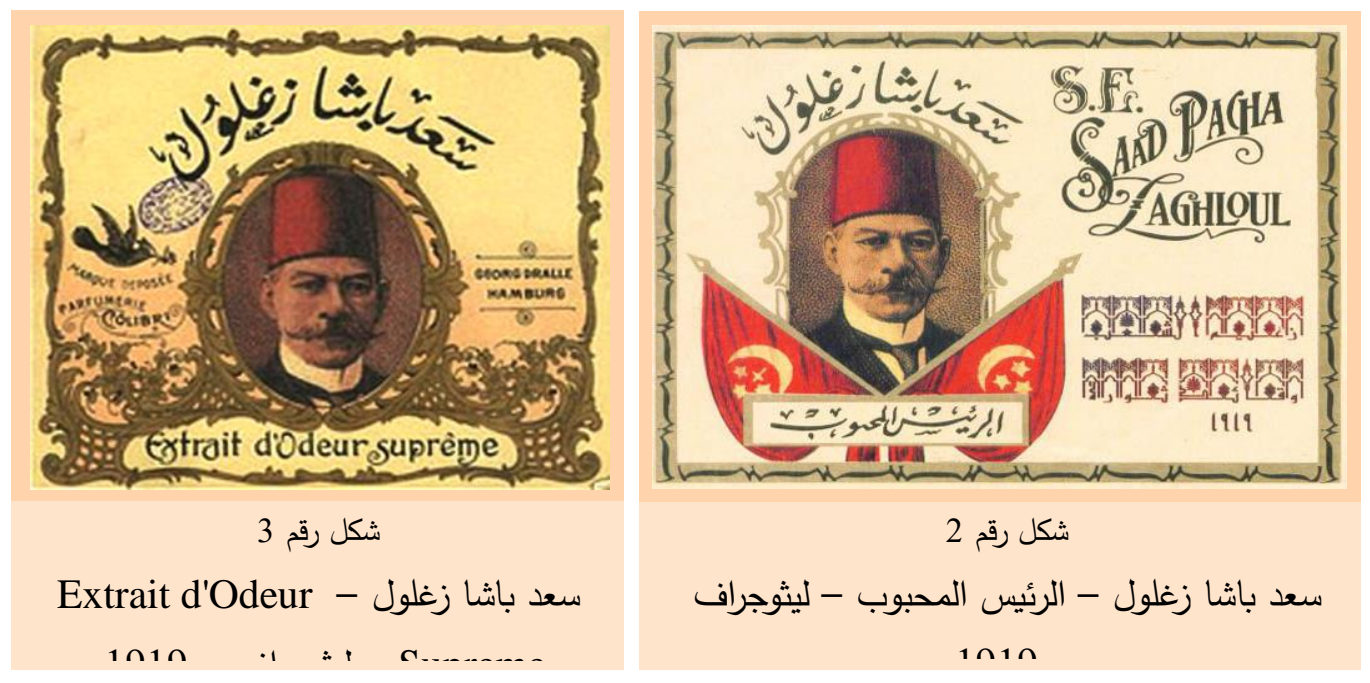

كما إنتشرت بعض من الملصقات التي تعبر عن حب المصريين لـ " سعد باشا زغلول " وتؤكد على نظرتهم له كمنقذ

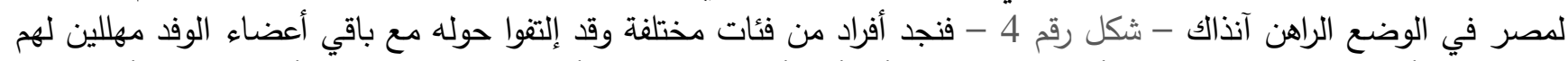

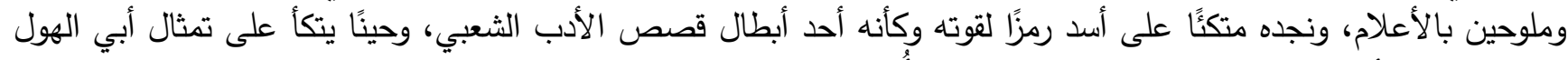

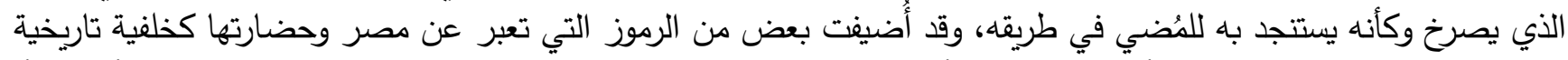

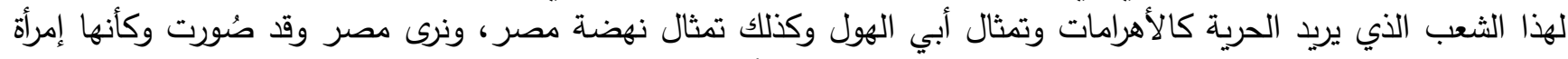
ترتدي التاج وتلتف بالعلم تارة وترتدي الزي المصري القديم تارة أخرى في إثارة لدعم مصر ككيان معنوي لله، ويعد تصوير 


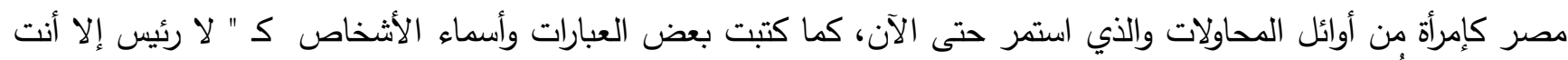

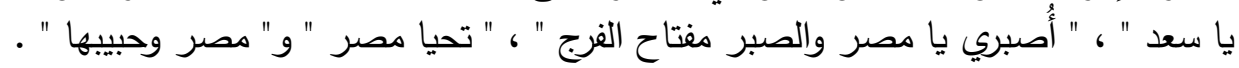

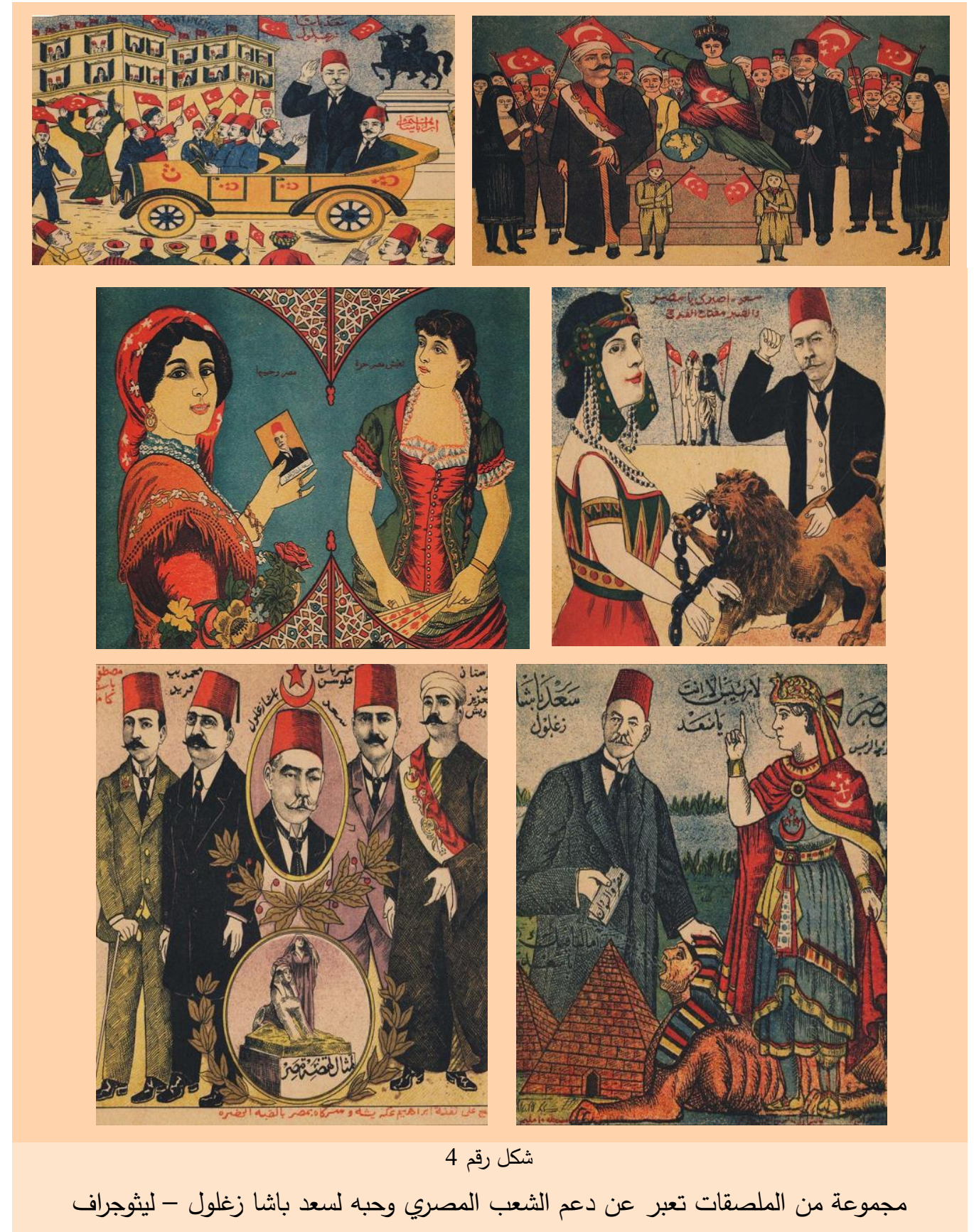

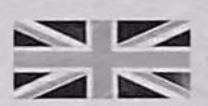

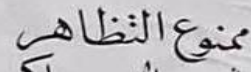

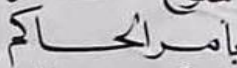
ألسكي البريبلن 19 i9

demonstrations are inhibited by order of the British military Governor

شكل رقم 5
وعلى الجانب الآخر فقد كانت بريطانيا تحاول بكل الطرق قمع هذه المظاهرات

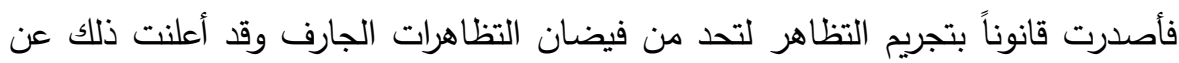
طريق ملصق تم لصقه في الثوارع والميادين بكل المحافظات - شكل رقم 5 - فنلاحظ بساطة التصميم من الناحية البصرية والذي إقتصر على علم بريطانيا بأعلى التصميم والتركيز على الرسالة المراد إيصالها للشعب وهي الكف عن التظاهر وقد كتبت باللغتين العربية والإنجليزية، ورغم هذه البساطة إلا أن التصميم يحمل قسوة في التصميم تعبر عن رسالته الحادة وربما ترجع هذه القسوة كون الملصق صادر عن مؤسسة عسكرية من ناحية الإنية

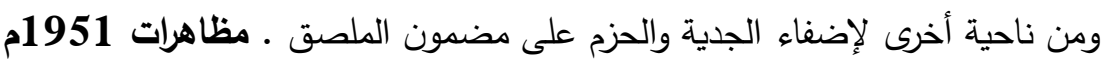


إحتضن ميدان الإسماعيلية - التحرير حاليًا - أول مظاهرة مليونية في تاريخ مصر، " ففي صباح يوم الأربعاء 14 من نوفمبر

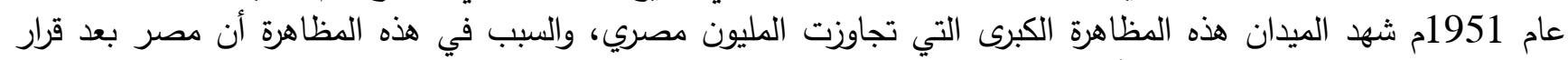

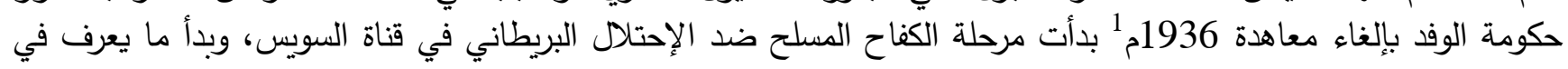

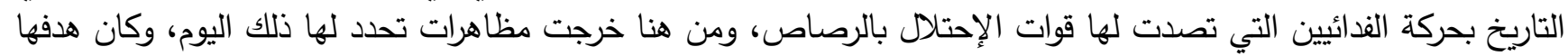

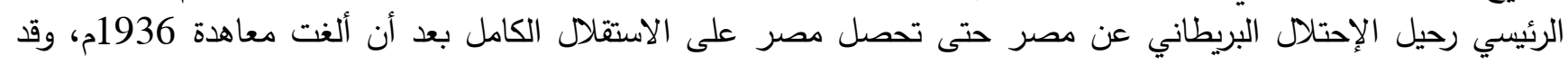

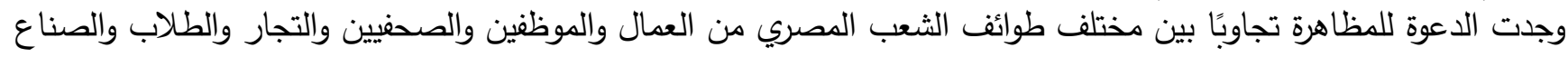
والقضاة والمحامين والصيادلة، وتم التخطيط للمظاهرة حيث جعلوها مظاهرة صامتة لكي تليق بجلال ذكرى الثهداء الذين الذين سقطوا برصاص الإنجليز "2.

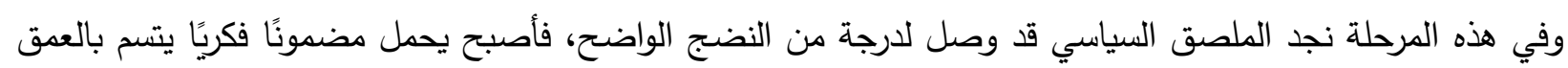

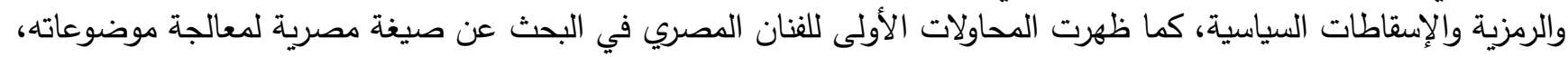

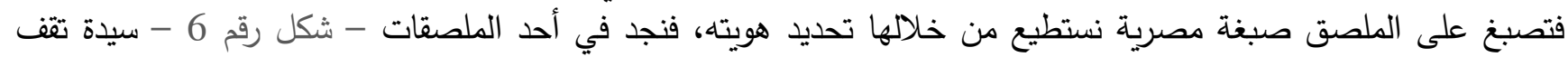

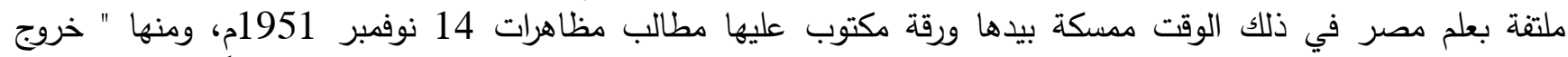
الإنجليز من بلادنا " وعلى يسار الملصق رجل في في الزي المصري المتعارف عليه في ذلك الحين يدهس رجلاً بريطانيًا بقدمها،

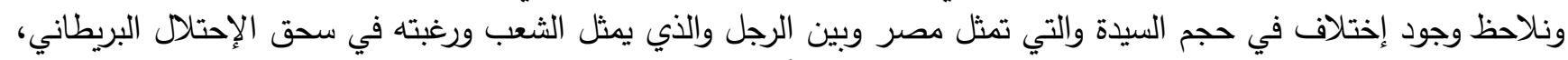

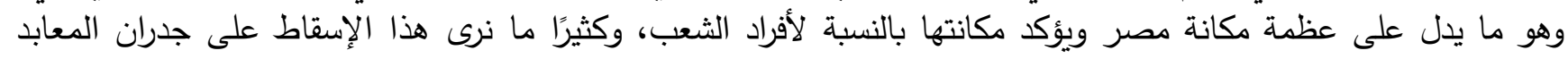

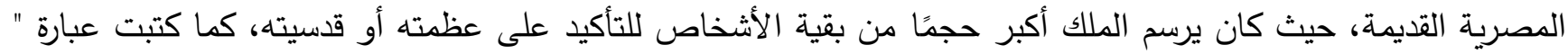

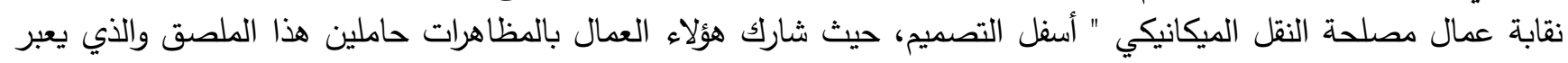
عنهم، كما نجد ملصق يتسم بالثورية ويقترح الحل للخلاص من هذا الإحتلال، - شكل رقم 7 هـ - ويحمل عبارة " بهذا نطرد

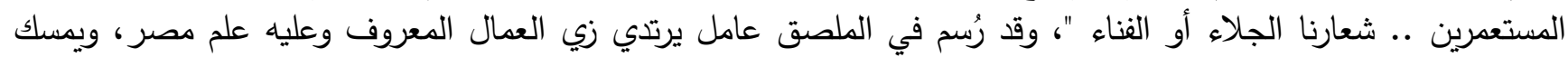

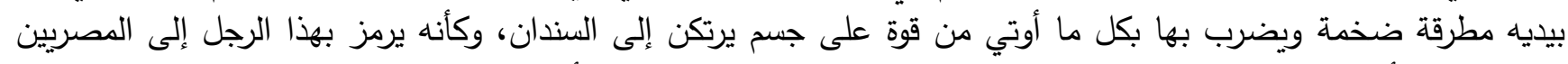

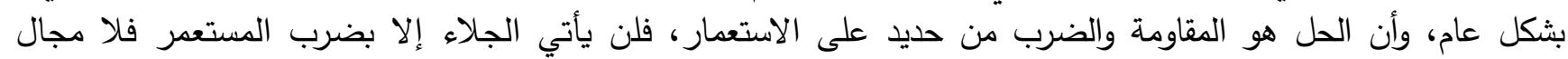

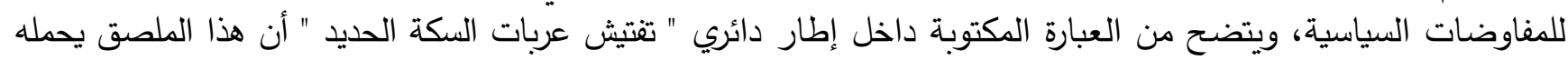
هؤلاء العمال أثناء المظاهرة .

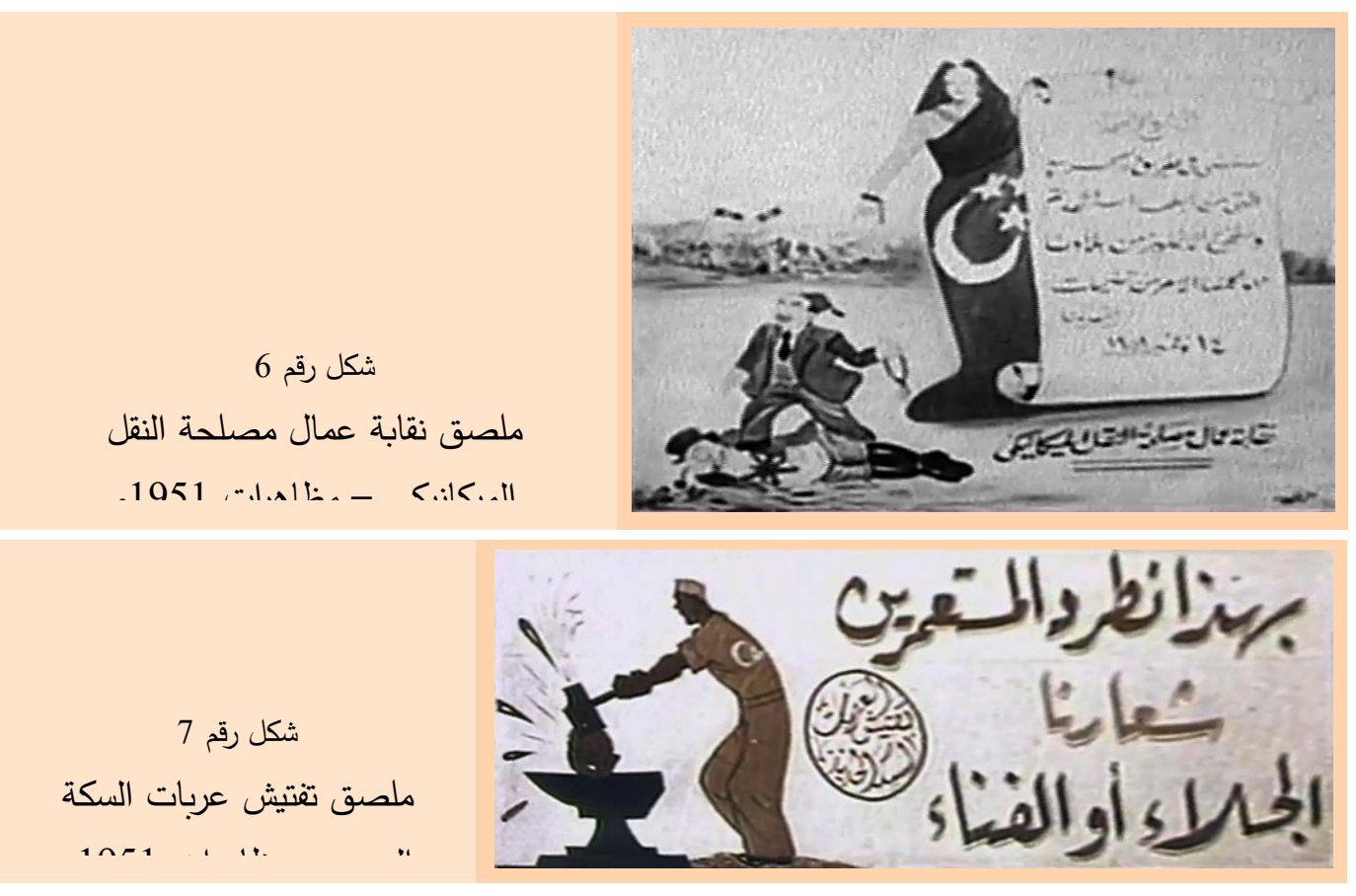

1 المعاهدة البريطانية المصرية عام 1936م بموجبها حصلت مصر على إعتراف باستقلالها، وإنسحاب القوات البريطانية من كل الددن وإقتصار تواجدها في منطقة قناة السويس فقط، ولكن وجهات

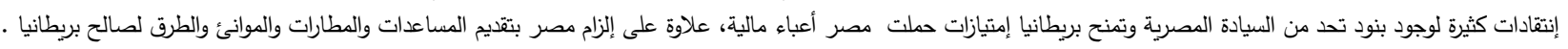

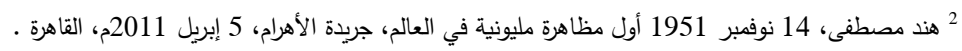


ونجد في ملصق آخر يحمل عبارة " سحقًا للظالمين .. سحقًا للمعتدين " - شكل رقم 8 - إعتمد تصميمه على يد كبيرة

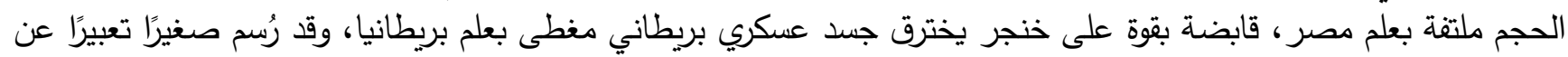

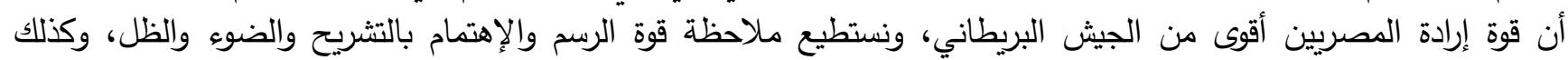

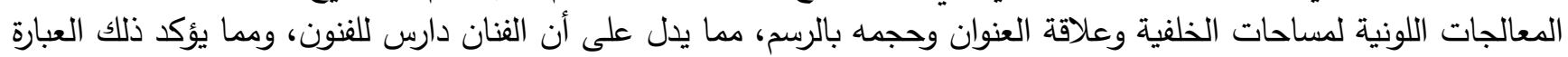

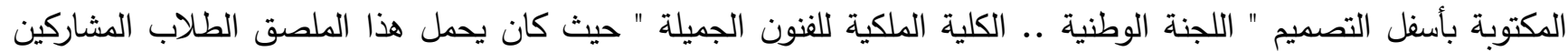

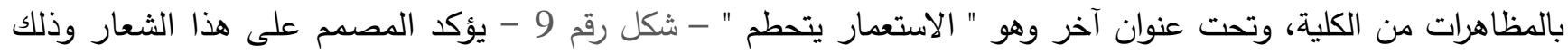

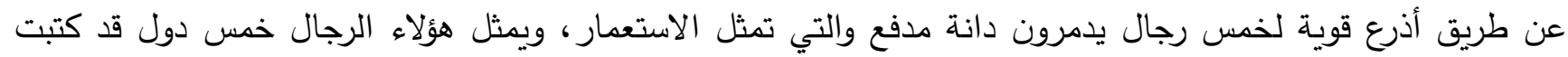

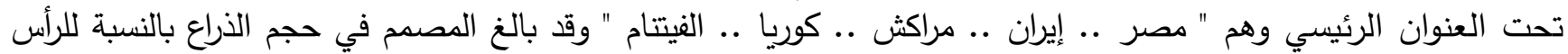

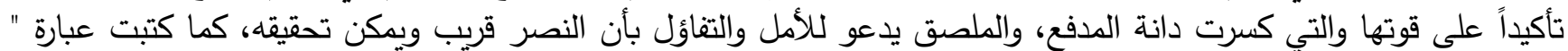

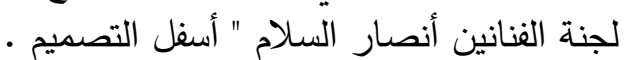

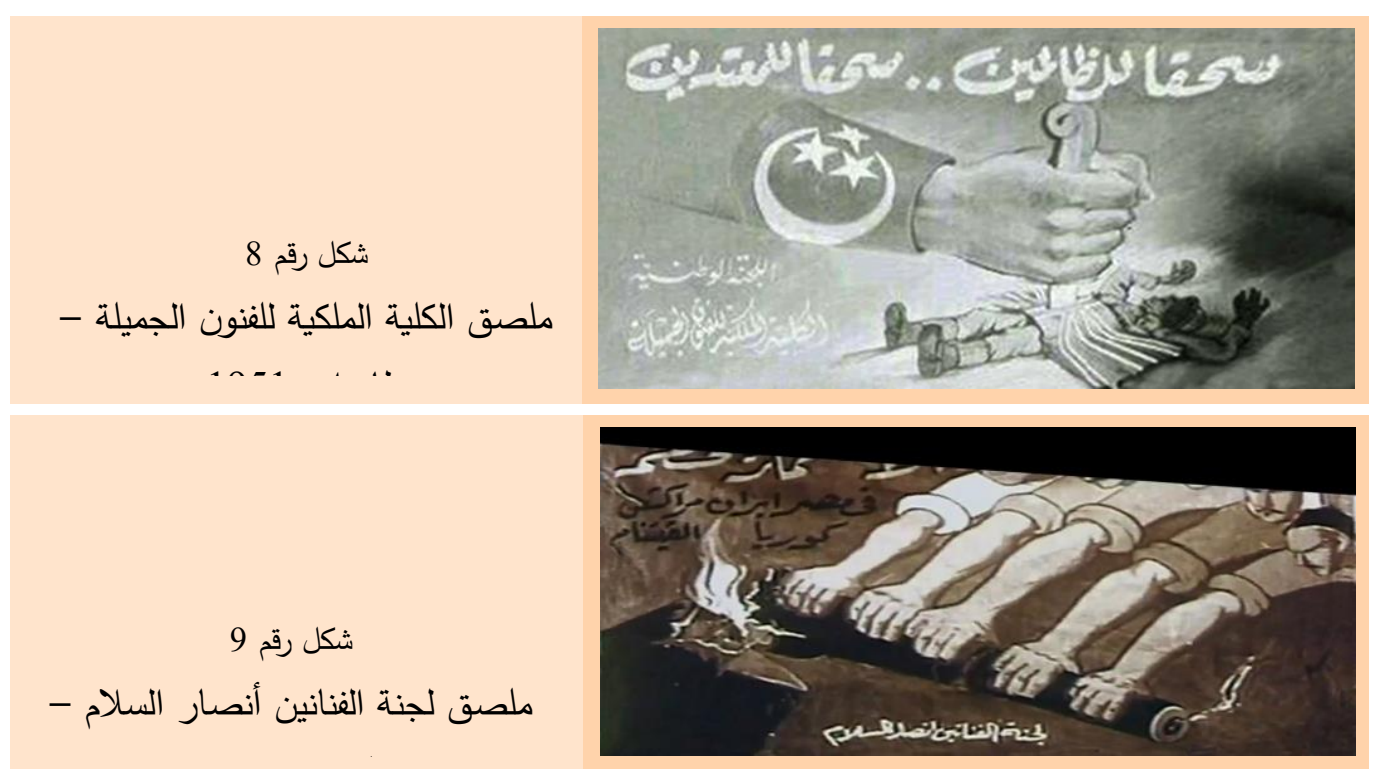

رُسمت مصر مرة أخرى كسيدة ترتدي العلم الوطني وتقف في حالة حزن - شكل رقم 10 - -، وملقى على الأرض بجوار

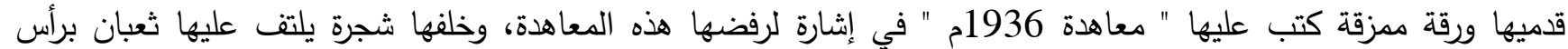

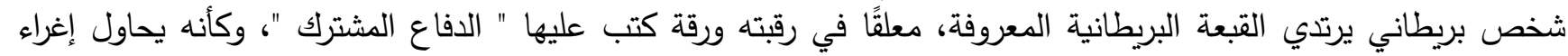

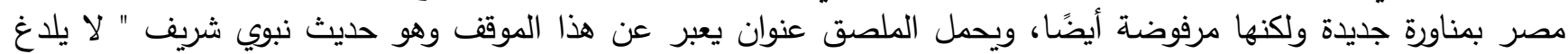

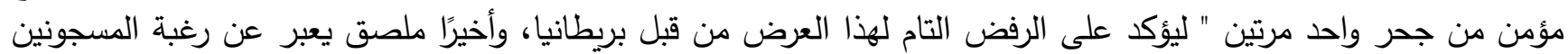

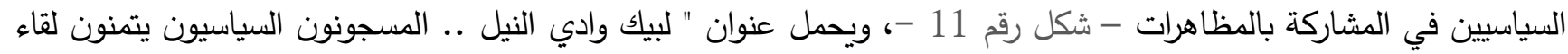

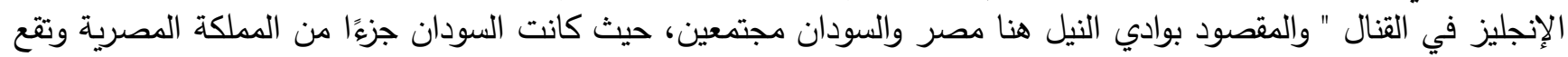

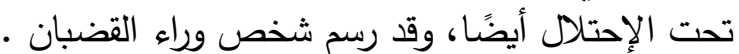
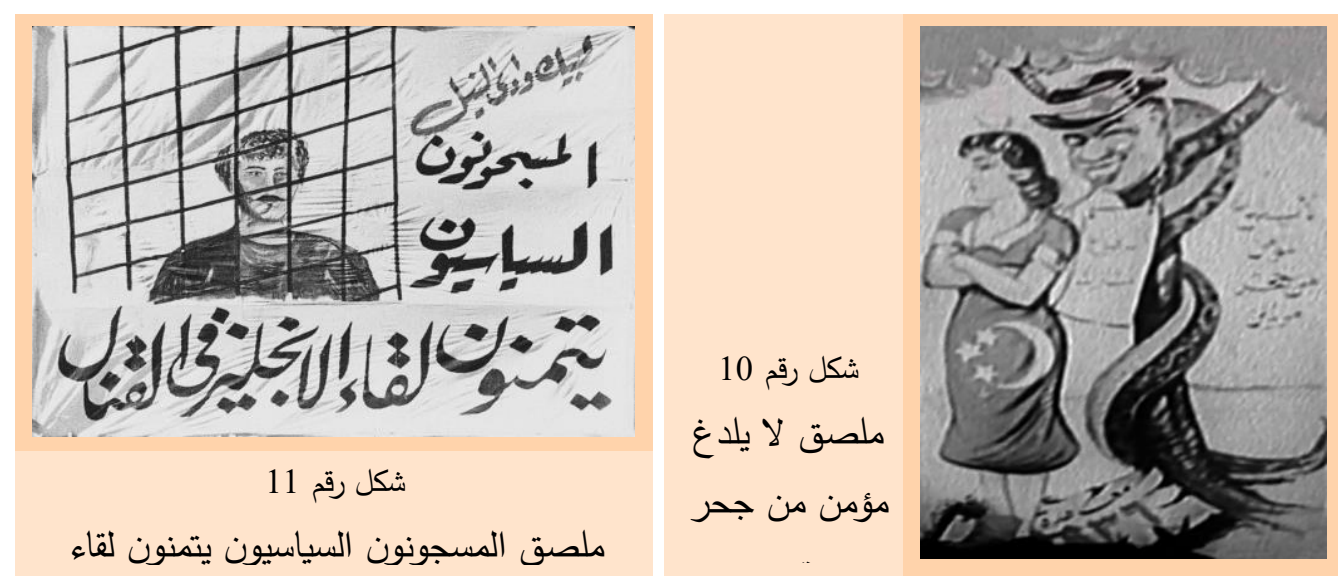


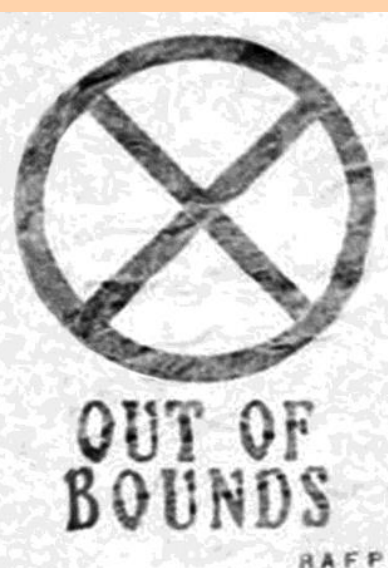

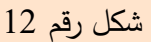

وقد قامت بريطانيا بتحديد أماكن تواجدها بمدينة

OUT OF " الإسماعيلية ووضع ملصق في مكتوب عليه BOUNDS

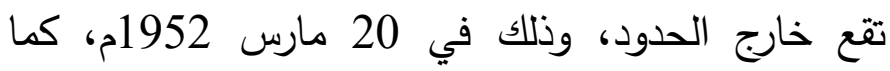

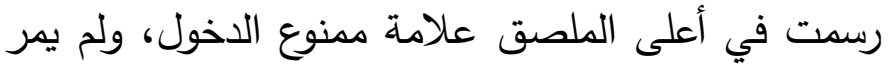
سوى ثلاثة شهور حتى قامت ثثرة 23 يوليو 1952م

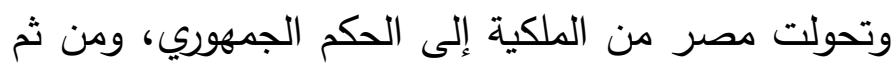
حثث تحولات سياسية وإقتصادية وإجتماعية كبرى .

ثورة 23 يوليو 1952م

قام مجموعة من ضباط الجيش عرفوا باسم " الضباط الأحرار " بإنقلاب عسكري ضد الملك " فاروق الأول "1 ، وإنهاء

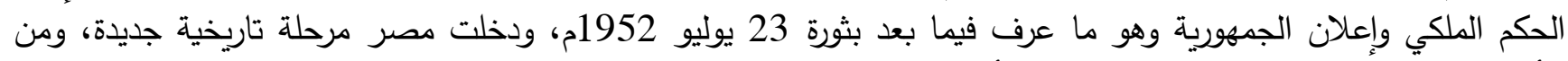

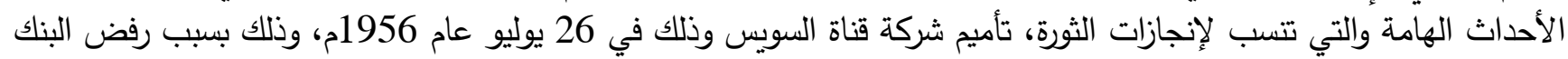

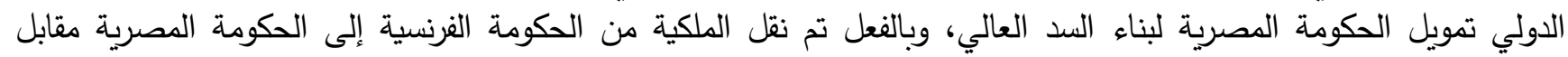

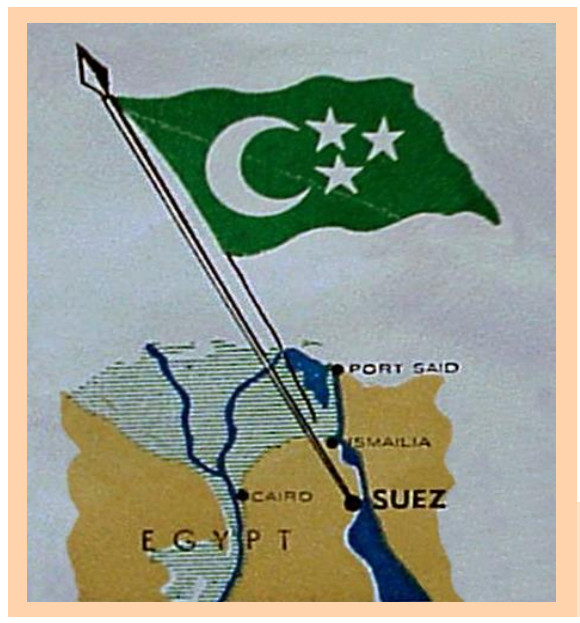

فنرى في هذا الملصق خريطة مصر موضحًا عليها قناة السويس - شكل رقم 13 --، وقد تم تحديد مدينة السويس بخط أكبر، ويخرج منها ساري يحمل علم مصر وقتذاك بحجم كبير ويتصدر التصميم تأكيدًا على مصرية قناة السويس، وأن مصر أصبحت ذات سيادة كاملة عليها . شكل رقم 13

ملصق بمناسبة تأميم شركة قناة السوس

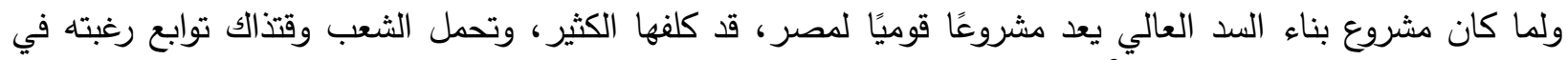

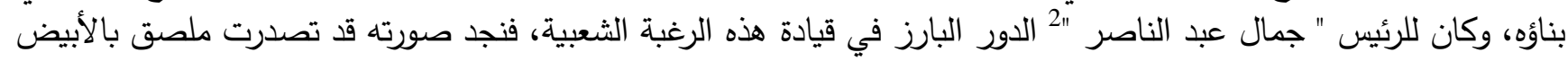

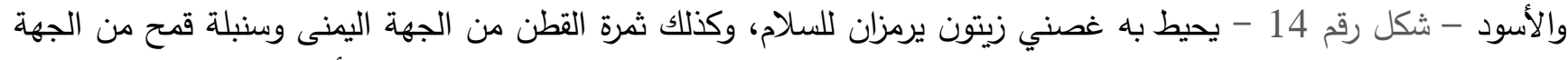

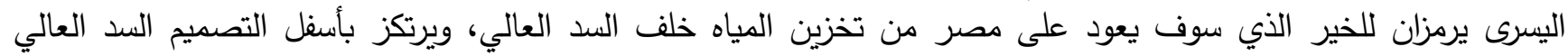

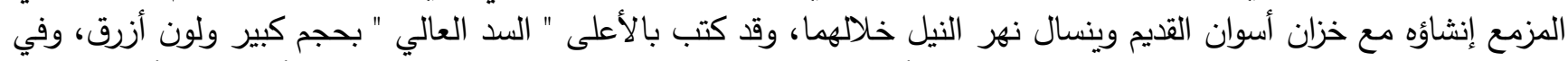

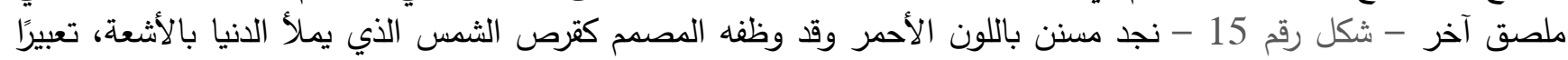

1 فاروق الأول ( 1920 - 1965م ) ملك مصر والسودان ( 1936 - 1952م ) أخر ملك حكم مصر فعلياً، تنازل عن العرش أثز الإنقلاب العسكري الذي قام به مجموعة " الضباط الأحرار " عام

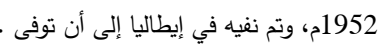

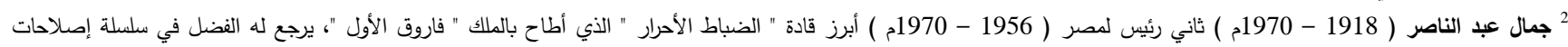

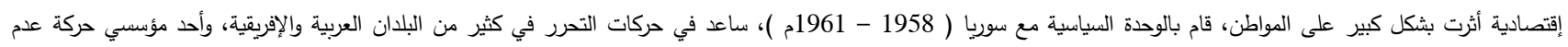


عن الكهرباء المتولدة من السد العالي، وستغمر مصر بالطاقة اللازمة للنهضة الصناعية المنتظرة، ووضع أمام المسنن ثرة

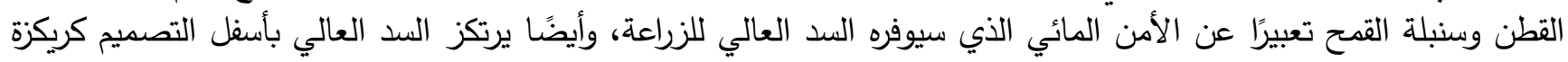

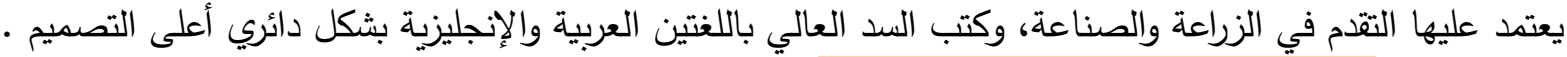
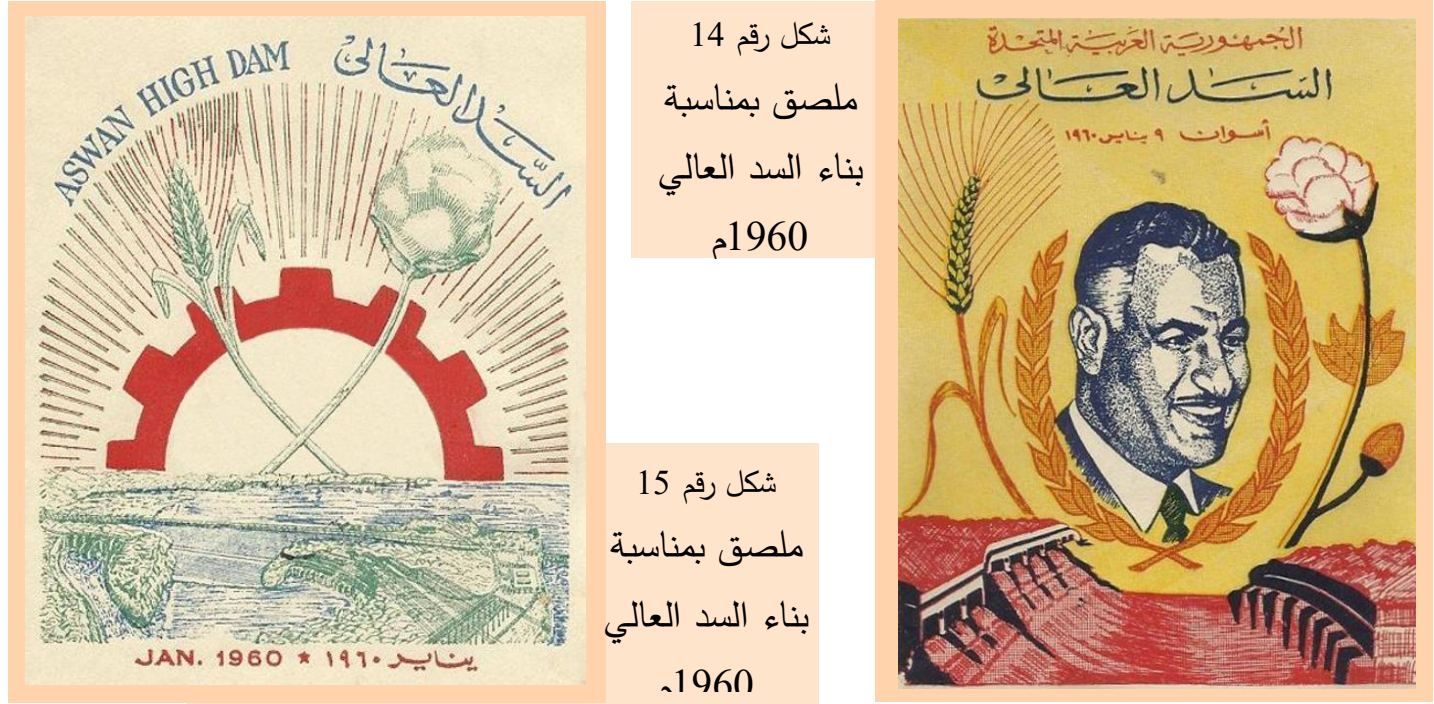

قام الرئيس " جمال عبد الناصر " بإنشاء العديد من المصانع الكبرى، والتي تدعم إقتصاد مصر وتساهم في النهضة

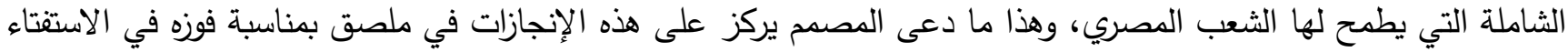

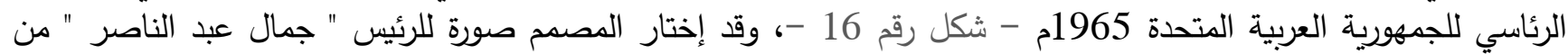

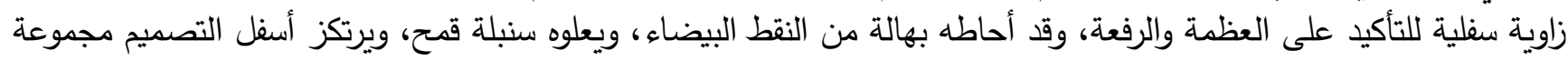

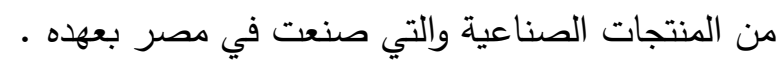

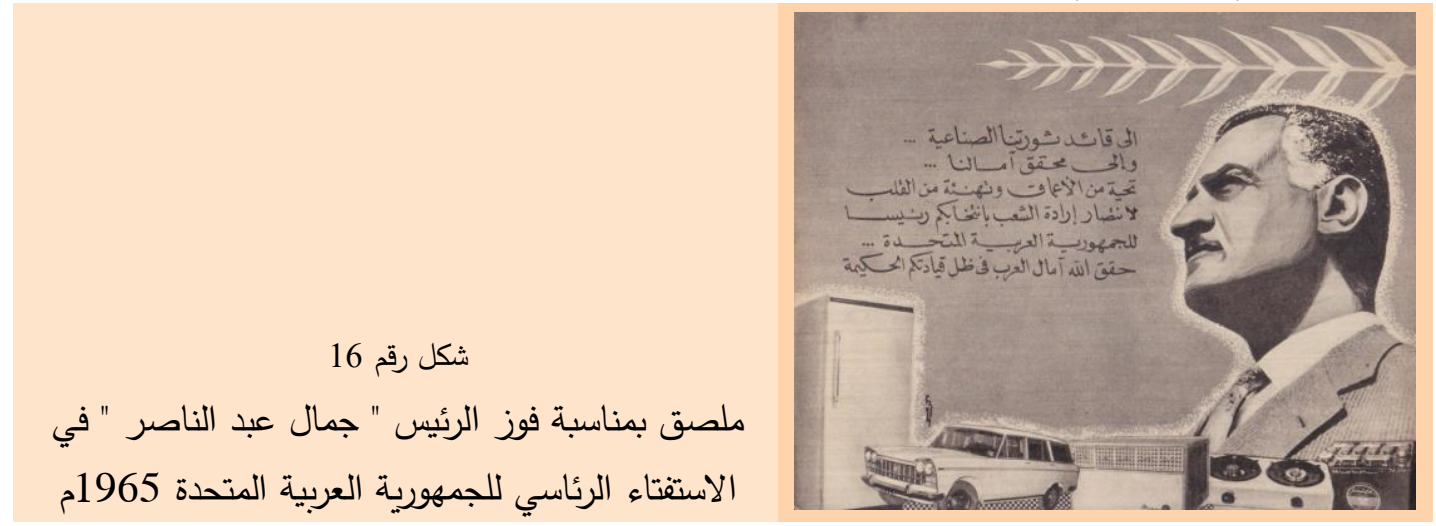

الإنتخابات الرئاسية عام 2005م في عام 2005م جرت أول إنتخابات رئاسية تعددية مباشرة بعد ثورة 23 يوليو

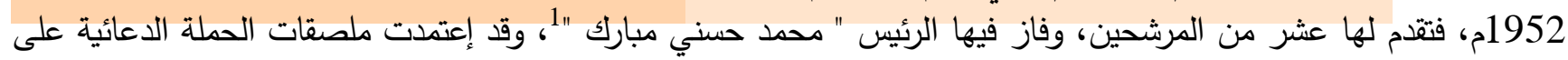
صورته فقط - شكل رقم 17 - وبجوارها كتب اسمه بخط كبير وتحته شعار حملته " القيادة ... والعبور للمستقبل " وقد تم تمات

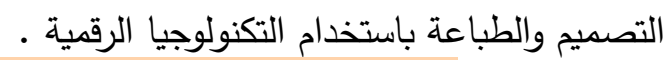

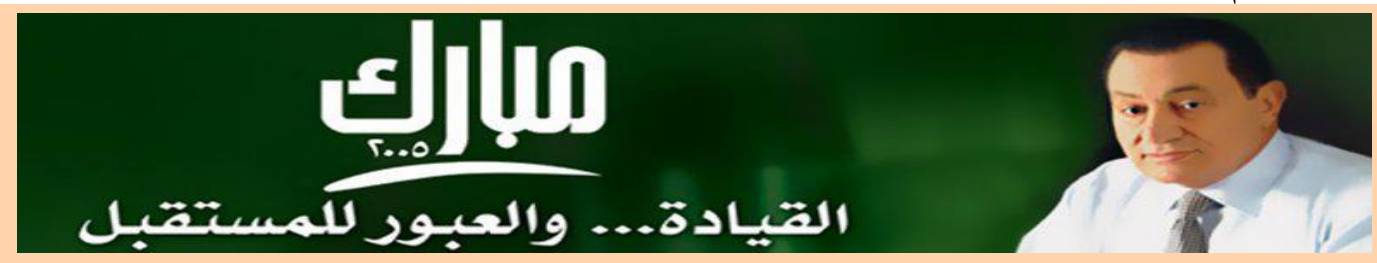

شكل رقم 17ملصق حملة " حسني مبارك " للرئاسة - رقمي

مؤتمرات الحزب الوطني الايمقراطي

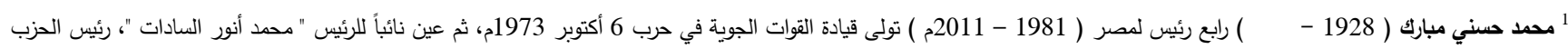

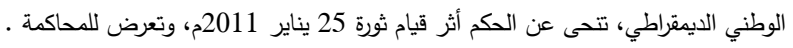


عقد الحزب الوطني الديمقراطي عدة مؤتمرات أخرها عام 2010م، وفي نفس العام استطاع أن يفوز بأغلبية ساحقة من

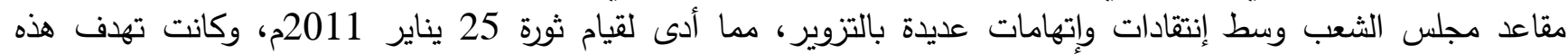

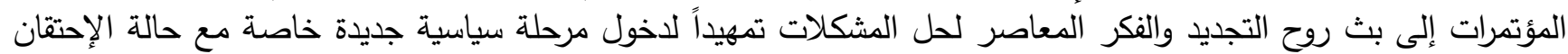

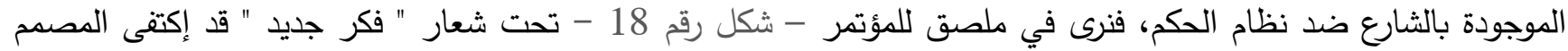

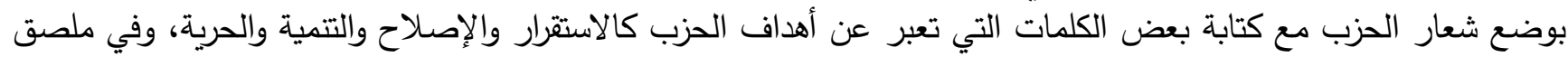

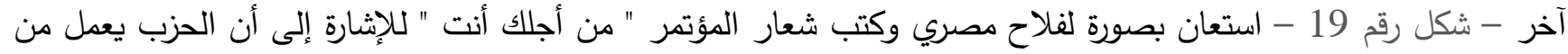

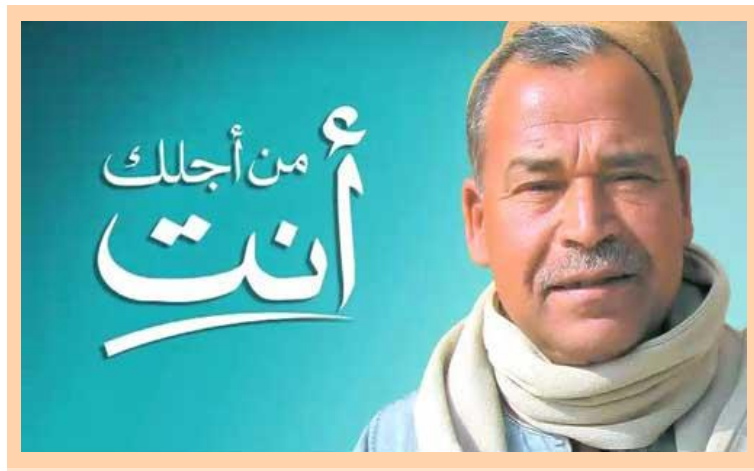

شكل رقم 19

ملصقة لمؤتمر الحزب الوطنح، الديمقراطح، عام

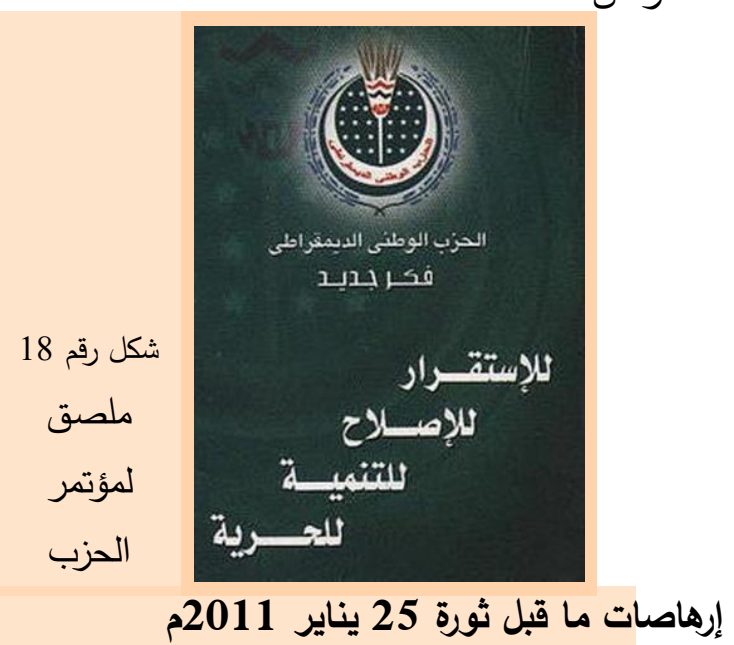

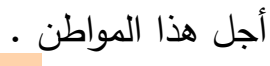

كانت لسلوكيات الثرطة تجاه المواطنين السبب المباشر لحالة الإحتقان التي سادت بين جموع الثعب وبالأخص الثباب

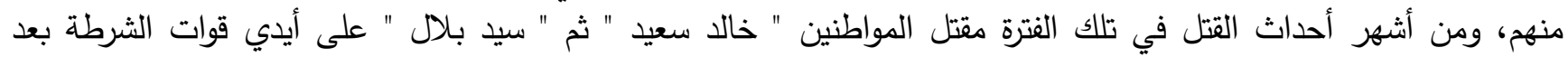

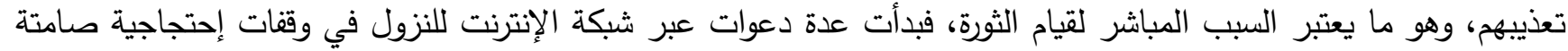

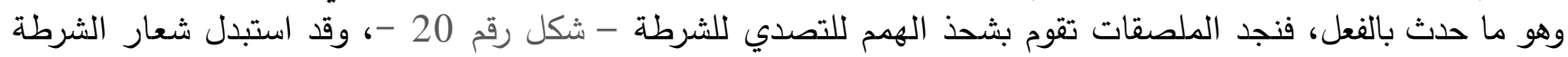
" الشرطة في خدمة الشعب " بشعار " الشرطة لتعذيب الشعب " وصورة لشرطي يحمل عصا بيده وملطخ بدماء المعذبين وقد وفار عولجت الصورة بمرشح بواسطة برنامج Adobe Photoshop، كذلك ملصق يدعو لوقفة صامتة بكورنيش الإسكندرية - شكل

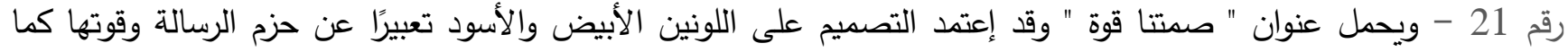

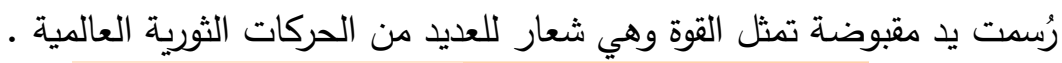
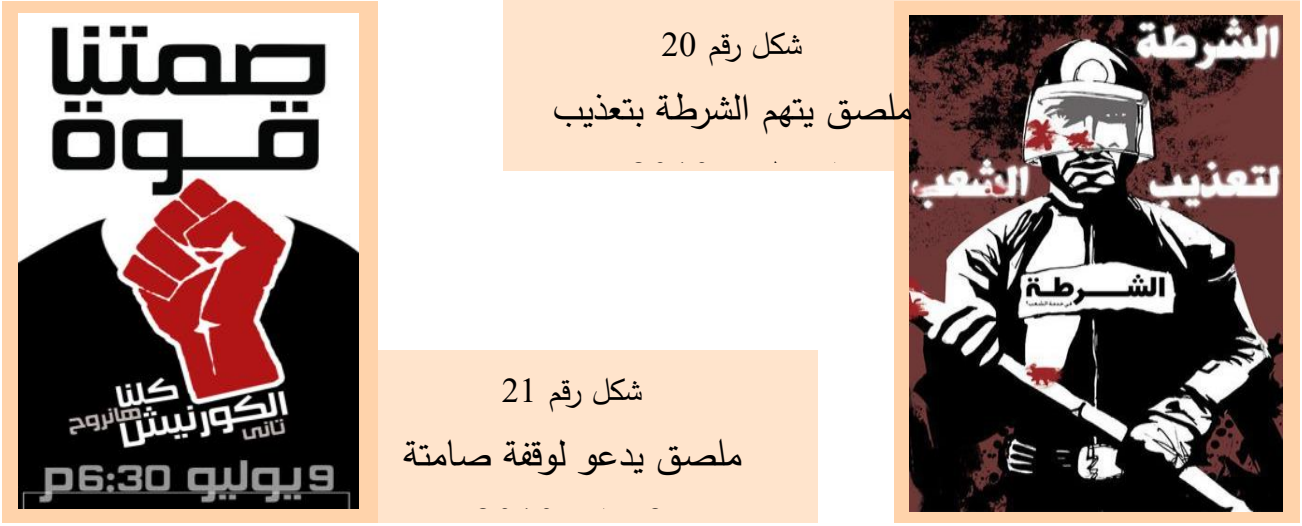

ثورة 25 يناير 2011م 
إنتشرت دعوات لنزول ميدان التحرير من خلال مواقع التواصل الإجتماعي، وقد حددت يوم 25 يناير 2011م كموعدًا،

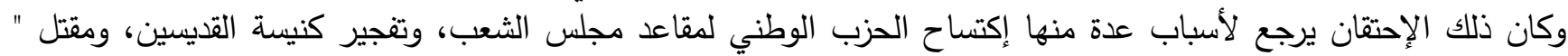

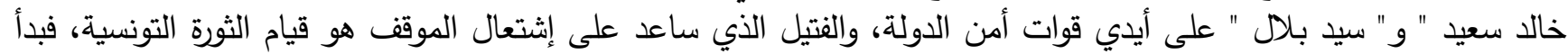

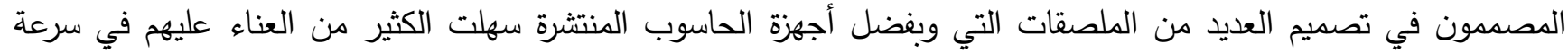
تتفيذها، ولذلك نجد من أشهر الملصقات التي إنتشرت عبر مواقع التواصل الإجتماعي - شكل رقم 22 - إعتمد تصميمه على علم مصر وتوظيف علم تولتونس في الجزه التعلوي من العلم المصري ذو اللون الأحمر، تيمناً بالثورة التونسية التي أطاحت
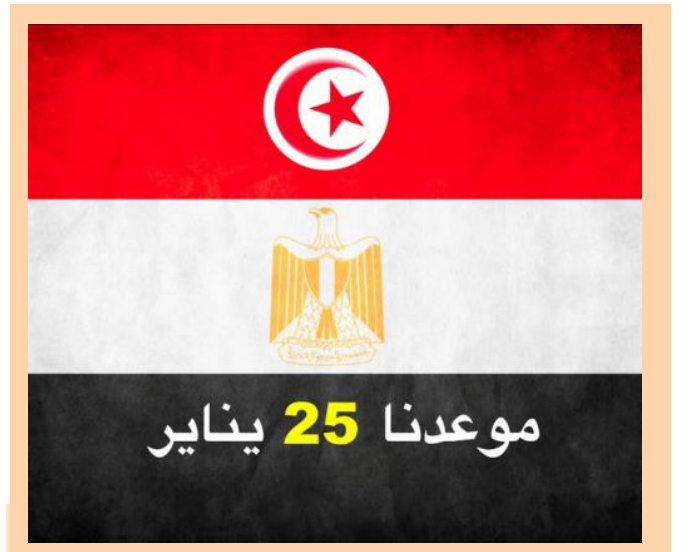

شكل رقم 22

ملصق يدعو للنزول للثورة يوم 25 يناير
برئيسها، وكتب اليوم المحدد للقيام بالثورة .

وبالفعل استجاب المواطنون للنزول وحدثت مواجهات مع الثرطة، واستمر التظاهر حتى يوم الجمعة 28 يناير والتي أُطلق عليها جمعة الغضب ووصلت المواجهات إلى ذروتها حيث كان يومًا مفصليًا في تاريخ الثورة، وقد بدأ الحشد لهذا اليوم بعد مواجهات يوم الثلاثاء 25 يناير ، وقد إعتمدت معظم الملصقات على اللونين الأبيض والأسود مع الأحمر تعبيراً عن

$$
\text { الدماء - شكل رقم } 23 \text { - - م }
$$

وقد استمرت المواجهات حتى سقطت الشرطة، ثم مكث الثوار داخل الميدان بعد نزول قوات الجيش للشارع لحفظ الأمن

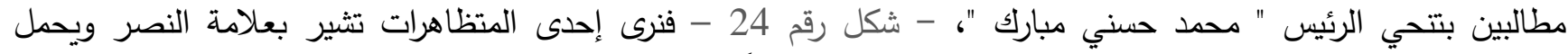

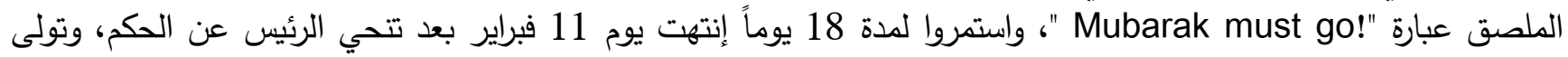
المجلس العسكري إدارة شئون البلاد حتى 30 يونيو 2012م، والإشراف على الاستفتاء على تعديلات الدستور ثم الإنتخابات

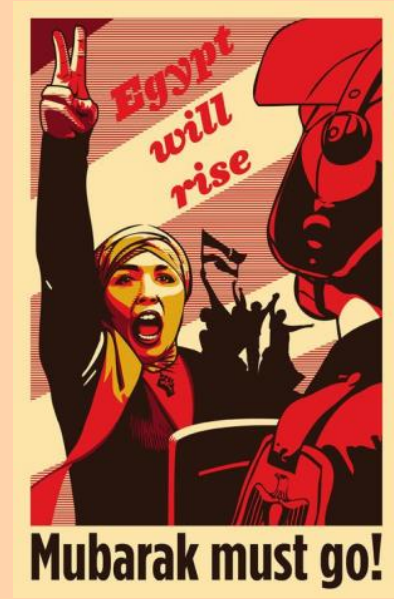

شكل رقم 24

ملصق يدعو لتححي الرئيس
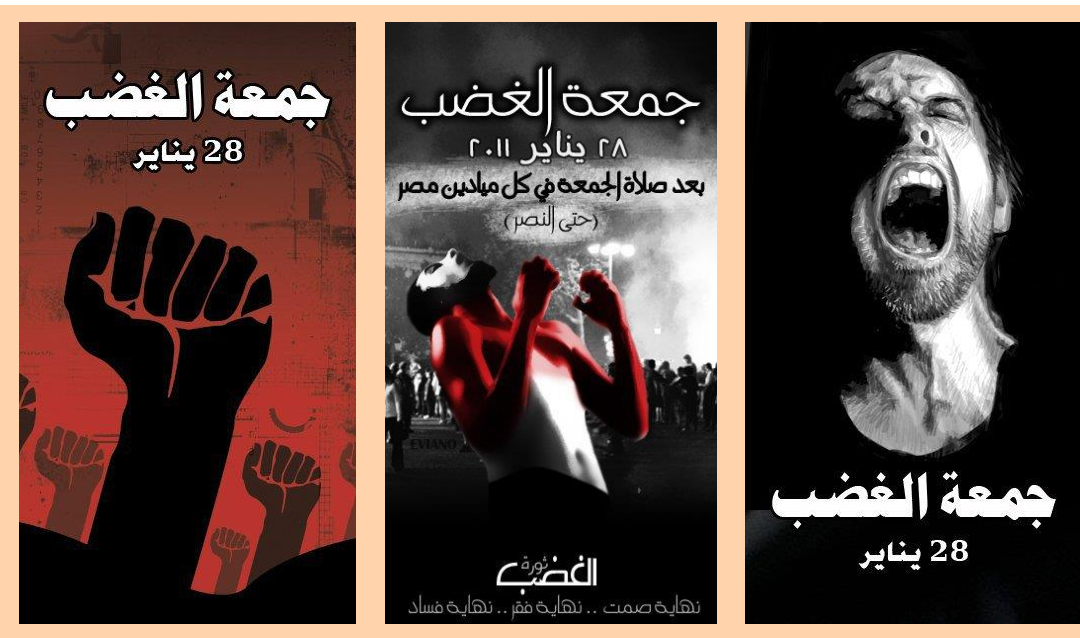

شكل رقم 23 الرئاسية .

وفي تلك الفترة التي قاربت السنة ونصف السنة كانت هناك أحداث عديدة، دعت الثعب للنزول مرة أخرى للميدان

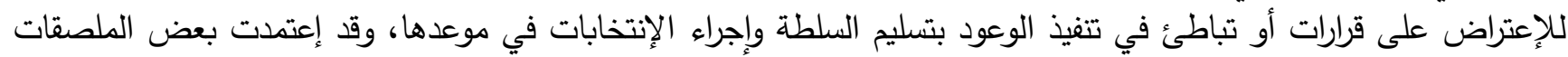

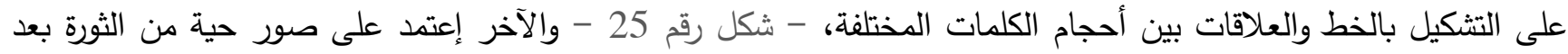

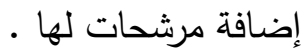



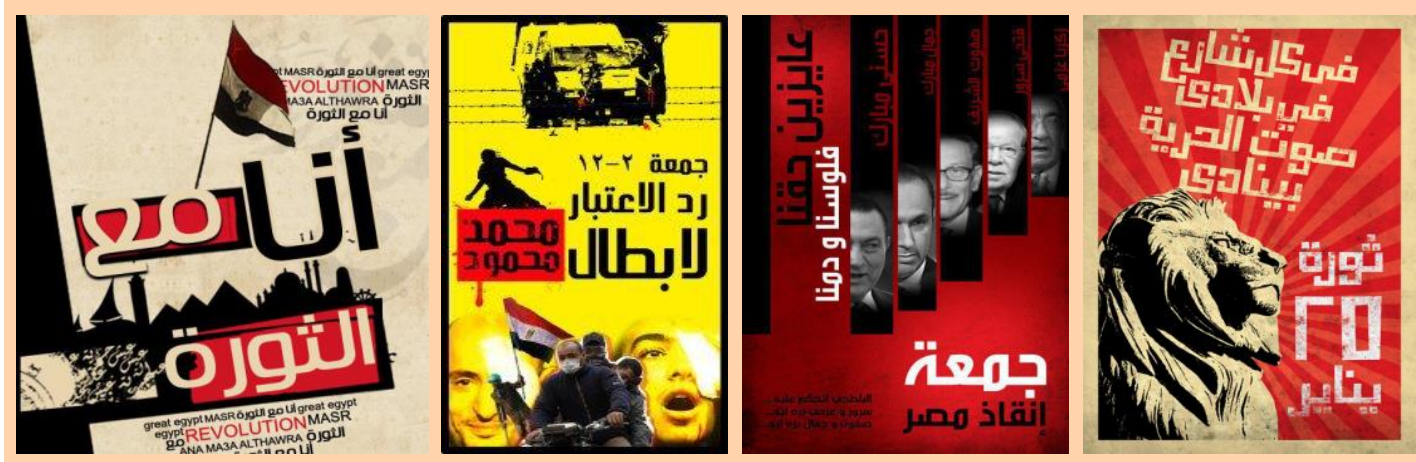

شكل رقم 25

ملصقات تدعو للحثد والمطالبة بإتخاذ قرارات من المجلس العسكري لتحقيق أهداف الثورة - رقمي

الإنتخابات الرئاسية عام 2012م

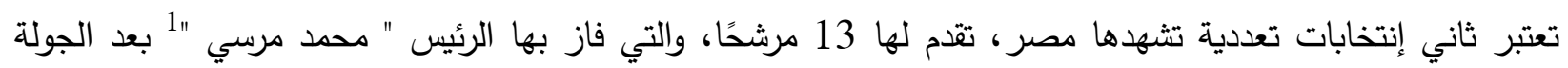

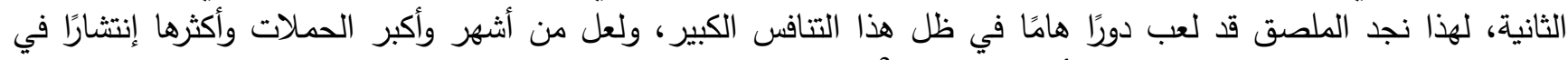

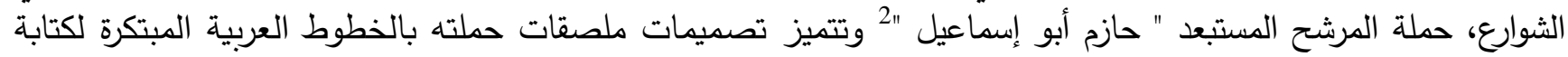

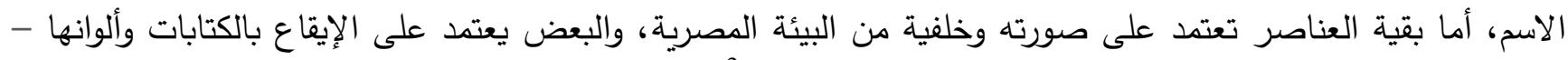

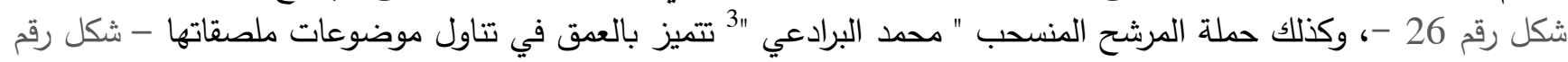

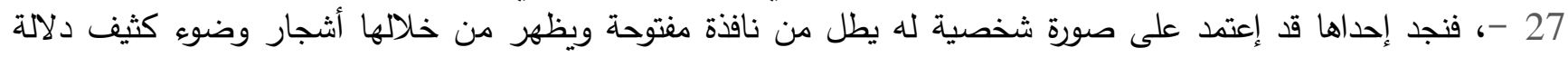

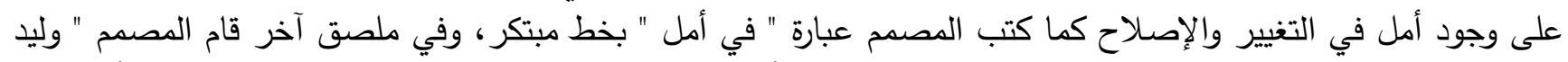

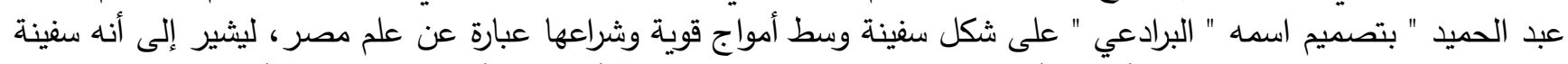

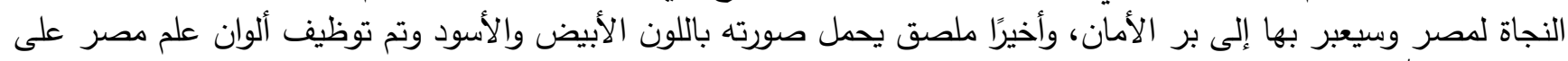

شكل علامة ل .

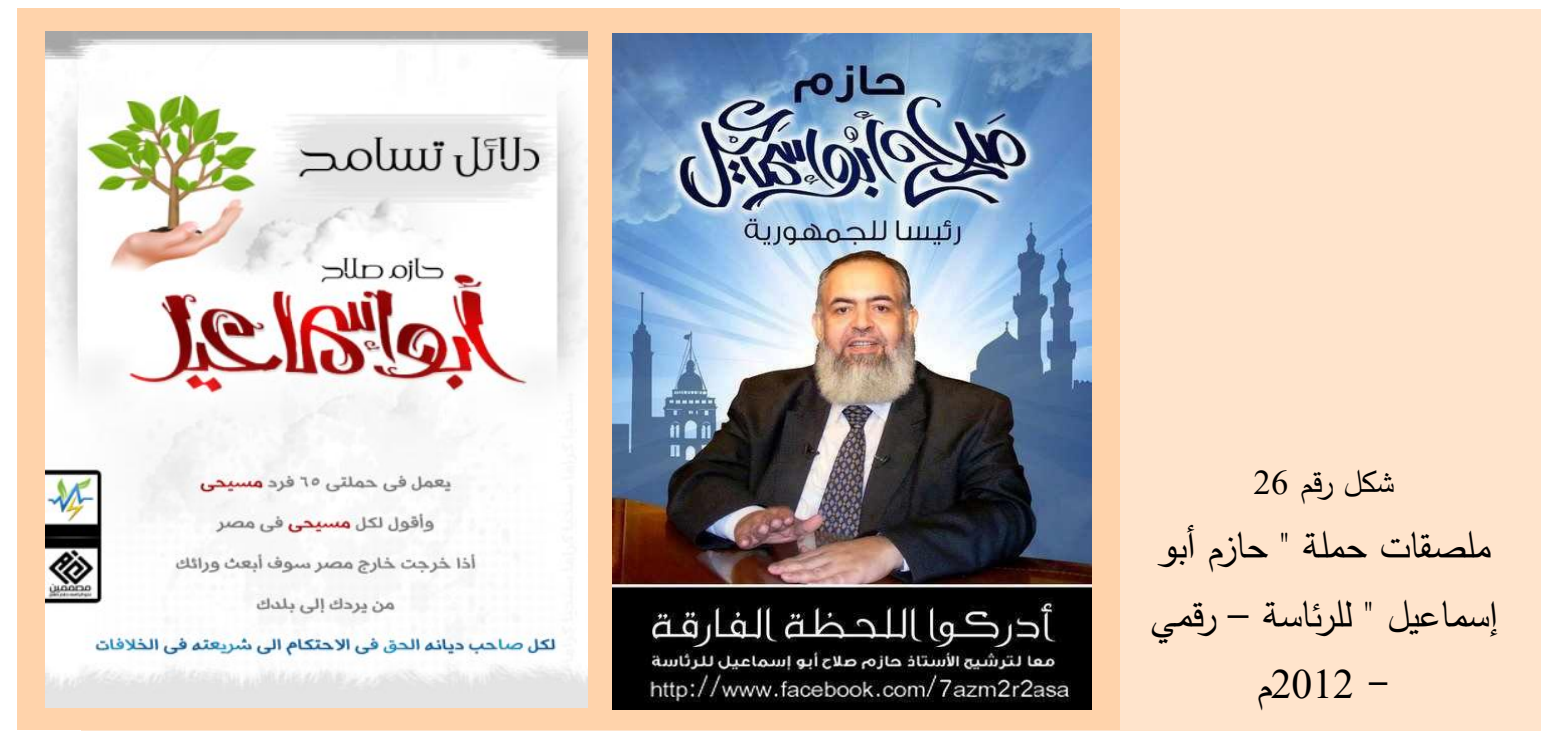

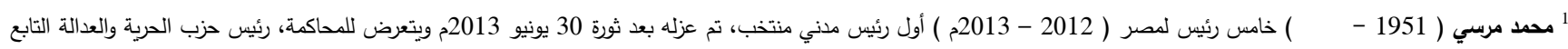

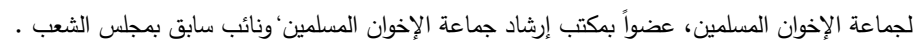

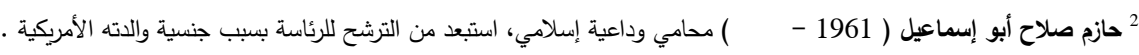

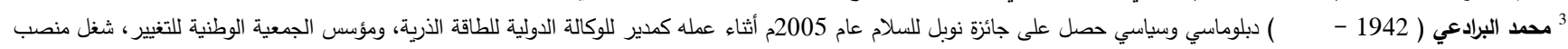




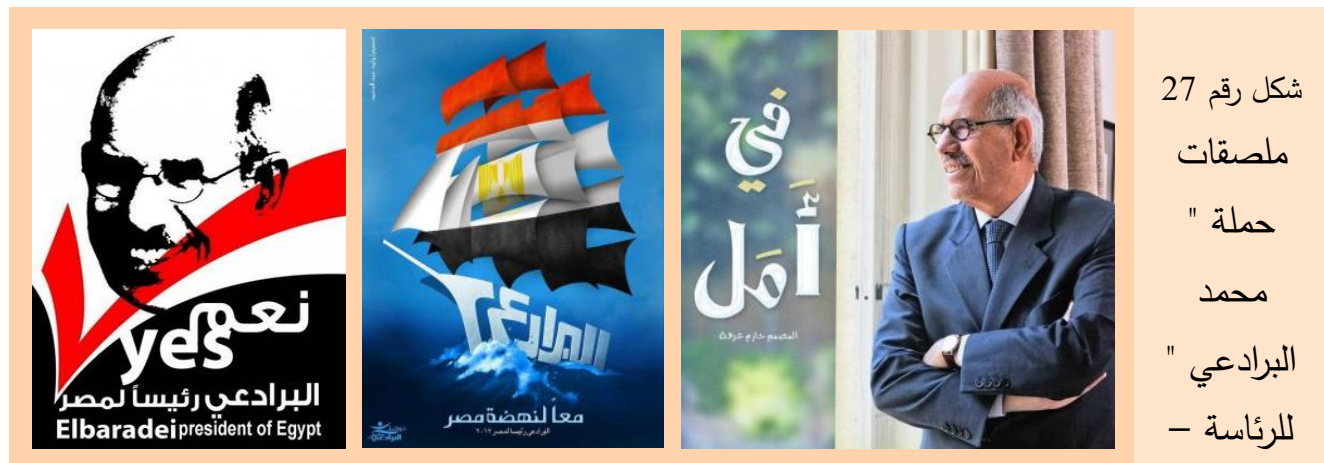

وهناك بعض الملصقات لمرشحين آخرين تحمل مضمونًا وليس مجرد صورة المرشح فقط، كملصق حملة المرشح "

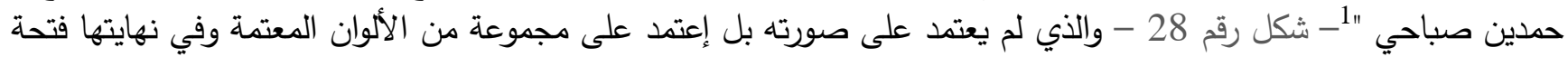
تتفذ إلى السماء يظهر منها الضوء وكأنه بصيص الأمل وسط هذه الظلمة، وطيور في السماء تعبيرًا عن الحرية المنشودة، كما

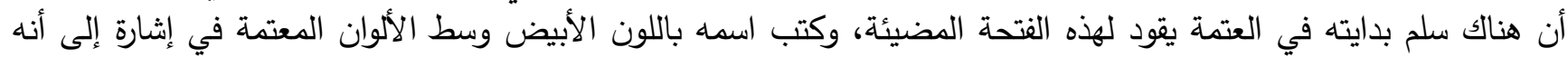

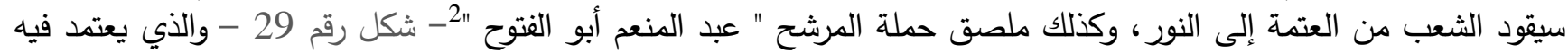

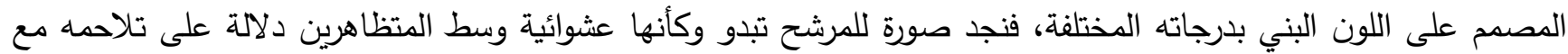

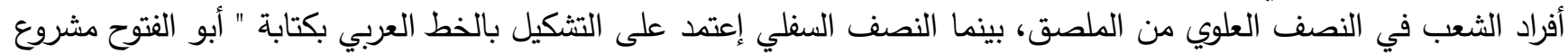
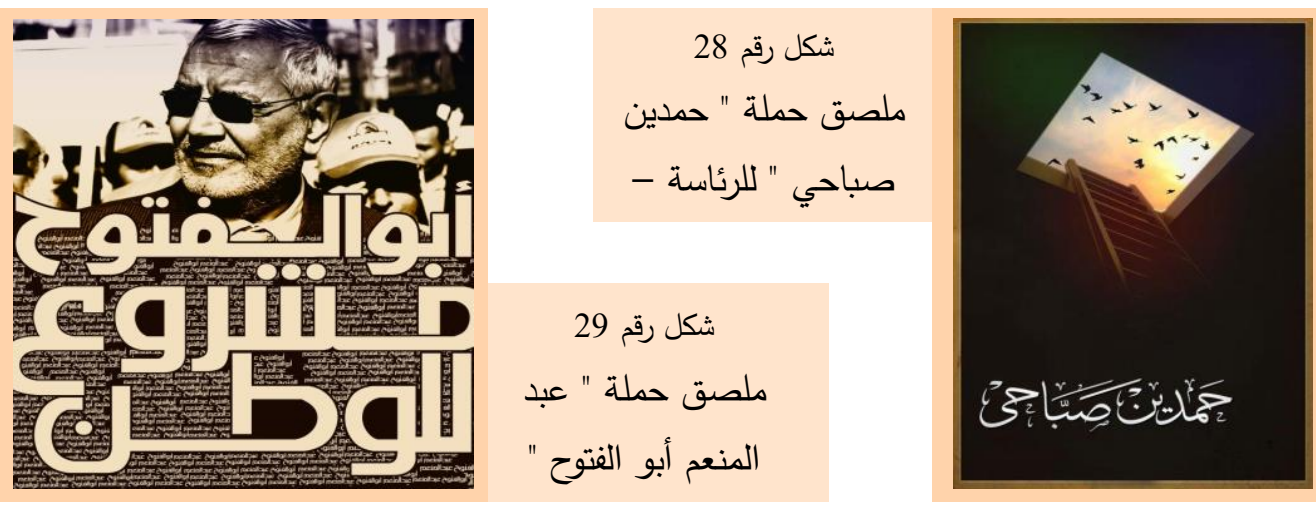

ثورة 30 يونيو 2013م

خلا فترة حكم الرئيس " محمد مرسي " شهد المجتمع إنقسامًا واضحًا وكان على وشك قيام حرب أهلية بين مؤيديه

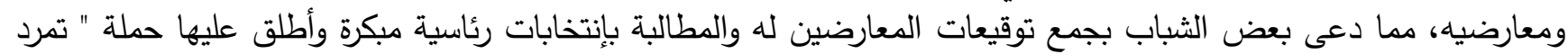

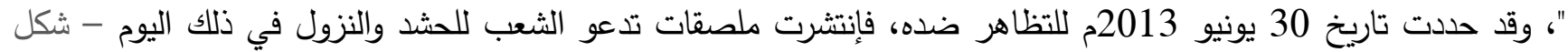

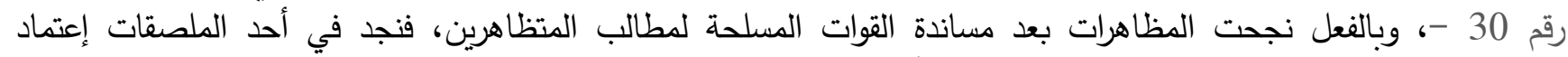

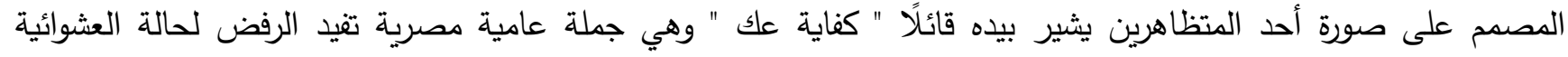

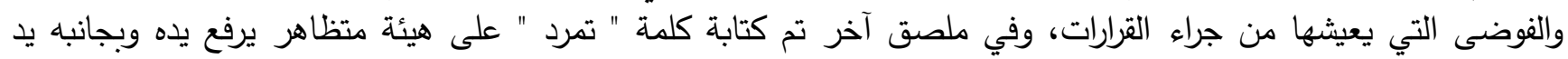

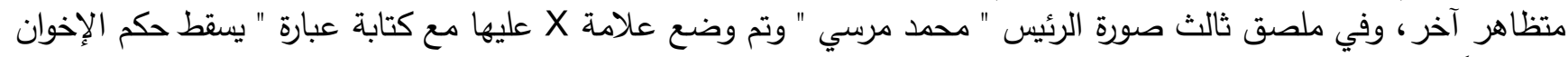

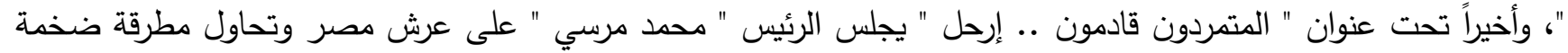

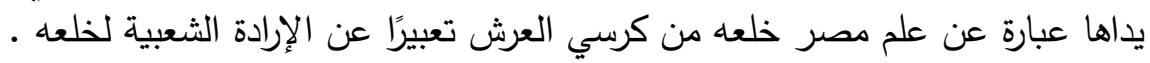



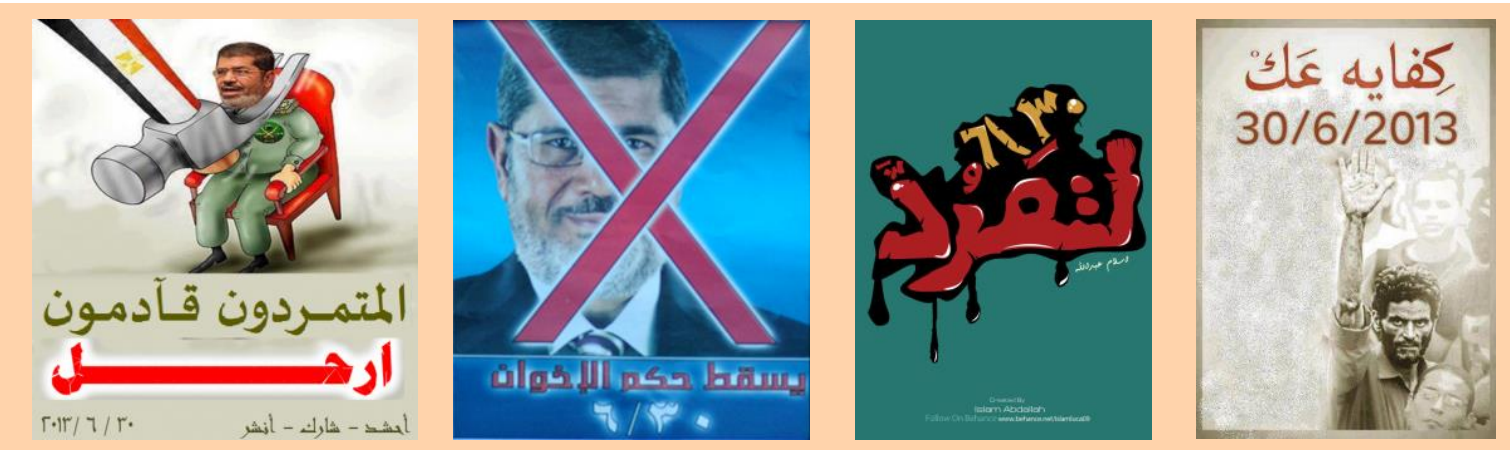

ملصقات تدعو لحثد الثعب ليوم 30 يونيو - رقمي - 2013م

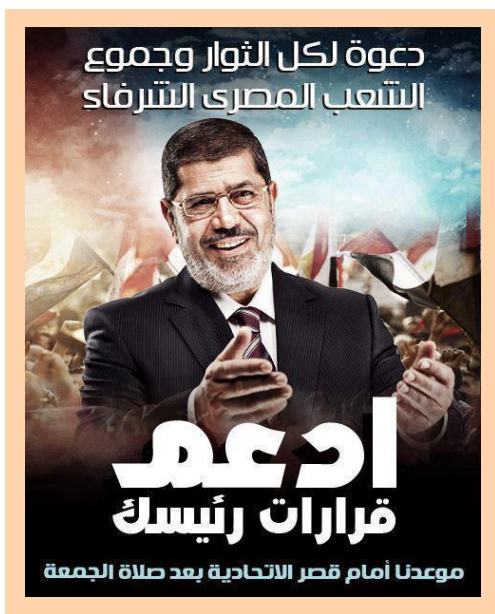

ومن ناحية أخرى فقد قام مؤيدي الرئيس " محمد مرسي " بحملات

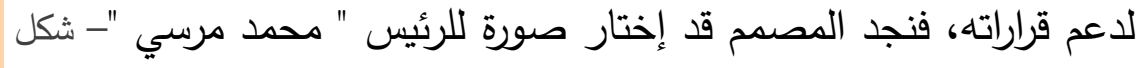

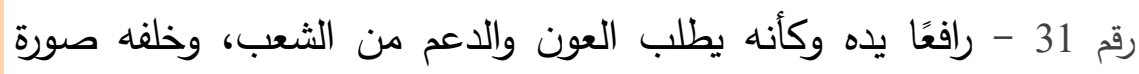

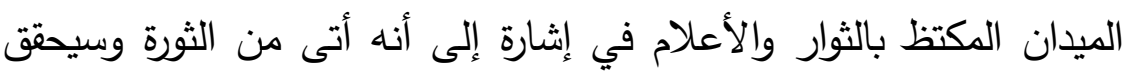

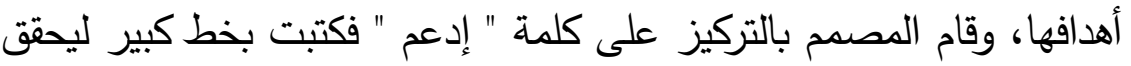

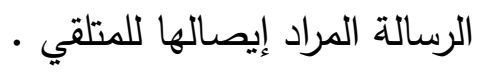

\section{شكل رقم 31}

ملصق يدعو لحثد المؤيدين لاعم قرارات الرئيس - رقمي - 2013م

\section{الإنتخابات الرئاسية عام 2014م}

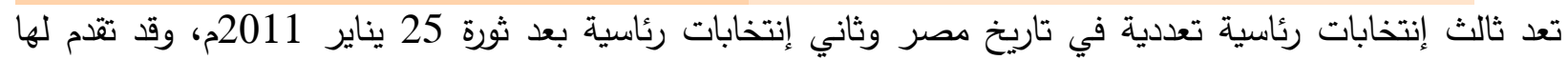

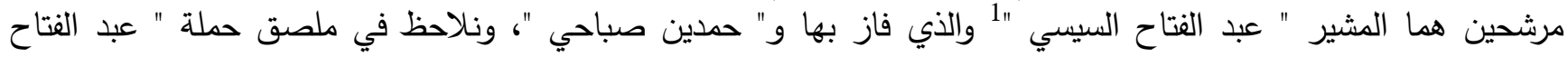

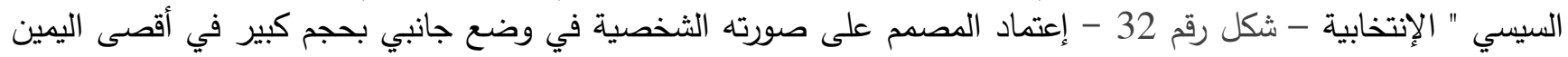

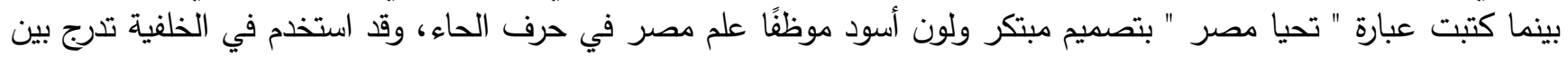

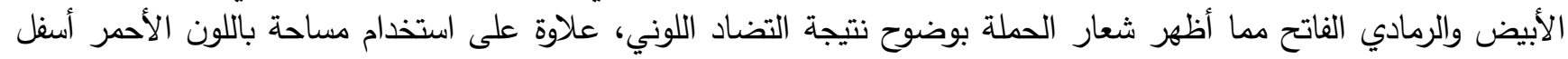

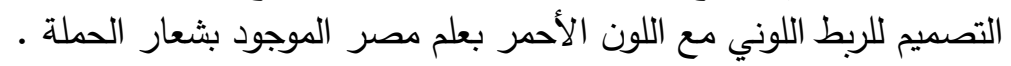

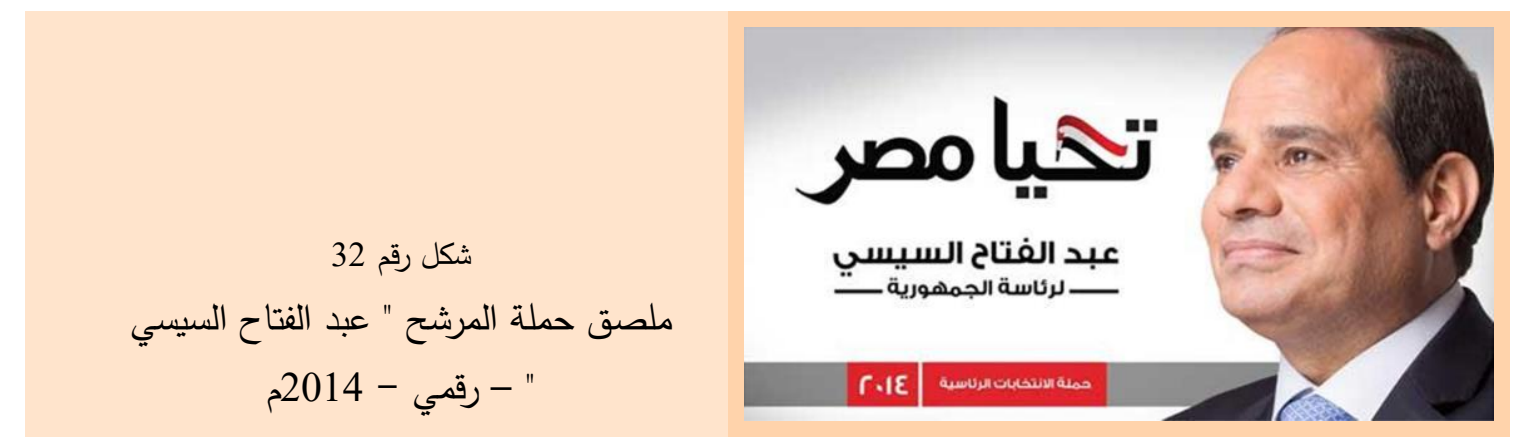

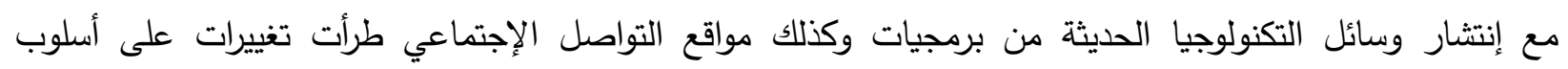

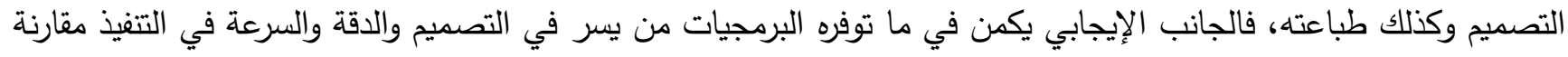




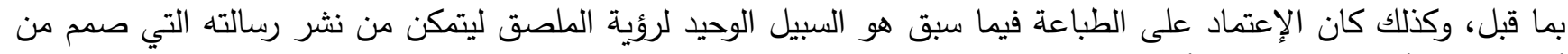

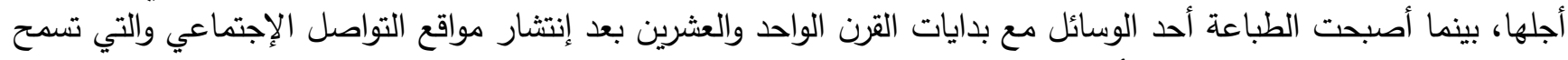

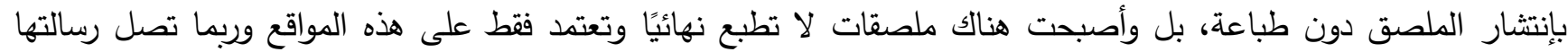

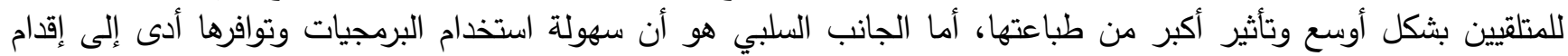

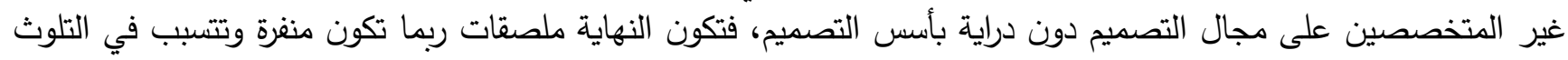

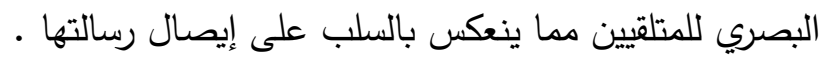

النتائج والتوصيات

- الملصق يلعب دورًا بارزًا في التعبير عن مبادئ وأفكار سياسية . - للمصمم دور فعال في التأثير على المتلقي من خلال الملصق وذلك عن طريق البحث عن حلول بسيطة لتوصيل الأفكار السياسية ونشرها .

- يجب أن تكلف جهة حكومية تقوم على عملية توثيق الملصقات والمطبوعات بشكل عام، حيث أنها فضلاً عن قيمتها

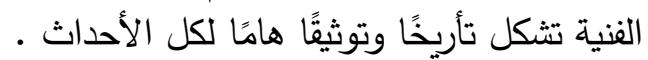

\section{المراجع والمصادر ومواقع الإنترنت}

- عبد الرحمن الرافعي - ثورة 1919م تاريخ مصر القومي 1914 - 1921م - مكتبة الأسرة - الهيئة المصرية العامة

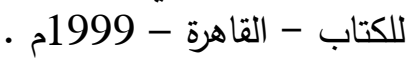

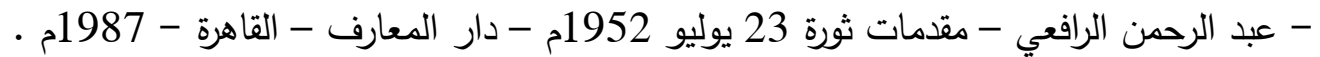

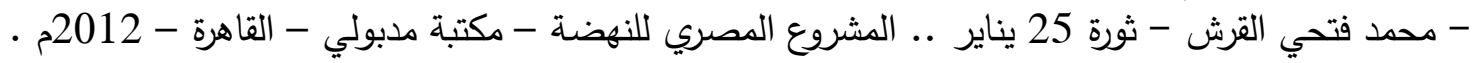

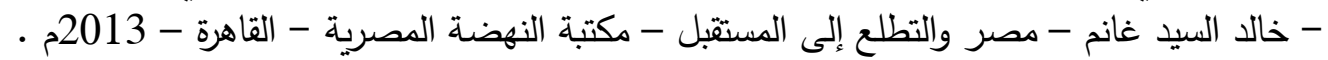

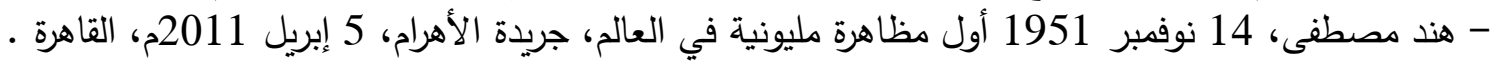
http://ar.wikipedia.org/wiki/ - 